\title{
Ending Abuse of Patent Continuations ${ }^{1}$
}

\author{
Mark A. Lemley ${ }^{2} \&$ Kimberly A. Moore $^{3}$
}

One of the oddest things to an outsider about the United States patent system is that it is impossible for the U.S. Patent and Trademark Office (PTO) ever to finally reject a patent application. While patent examiners can refuse to allow an applicant's claims ${ }^{4}$ to ownership of a particular invention, and can even issue what are misleadingly called "Final Rejections," the patent applicant always gets another chance to persuade the patent examiner to change her mind. Even stranger, perhaps, is that the PTO can't even finally grant a patent. Even when the examiner concludes that an invention is patentable and issues a "notice of allowance," the patent applicant always retains the right to abandon the application that was deemed patentable and start the process over again. Alternatively, an applicant can take the patent the PTO has awarded and at the same time seek additional or broader claims arising out of the same patent application. In all three cases, the culprit is what is known as the "continuation" application. ${ }^{5}$ Applicants dissatisfied with the course of patent prosecution can abandon an application and file a

1 ㄷ 2003 Mark A. Lemley \& Kimberly A. Moore.

2 Professor of Law, University of California at Berkeley (Boalt Hall); of counsel, Keker \& Van Nest LLP.

${ }^{3}$ Associate Professor of Law, George Mason University School of Law. I am grateful to the George Mason University Law and Economics Center for its continued support. We are indebted to the following firms who generously sponsored this research: Banner \& Witcoff, Howrey Simon Arnold \& White, Kenyon \& Kenyon, and Morgan, Lewis \& Bockius. Thanks are also due to Becky Eisenberg, Matthew J. Moore, Craig Nard, Harold Wegner, John Whealan and participants at a conference at Harvard Law School for helpful discussions of topics treated in this paper, Jim Hirabayashi at the PTO for assistance in compiling the data, and R. Derek Trunkey for statistical assistance.

4 The legal scope of an invention is defined by the "claims" of a patent, which set the boundaries of the rights granted in a patent. See Markman v. Westview Instruments Inc., 517 U.S. 370 (1996).

5 Continuation applications are governed by 35 U.S.C. $\S 120$. Statutory changes at the end of the last century changed the official terminology to "Continuing Prosecution Application", but did not otherwise affect the substantive rules governing continuation applications. See Request for Continued Examination Practice and Changes to Provisional Application Practice, 65 FED. REg. 50092, 50093 (2000). 
continuation. Alternatively, a patentee can prosecute one or more patents to issue and also keep a continuation application on file, hoping to win a better patent from the PTO in the future. We describe this rather remarkable practice in Part I. We also report the results of our comprehensive empirical study of continuation applications, which demonstrates the frequency with which this process is used and abused. In an effort to study the pervasiveness of this practice, we compiled an original dataset comprising 2,224,379 patents, every patent issued from 1976 through 2000. We obtained the data on the patent filing dates, issuance dates, whether the patent claimed priority to an earlier filed application, the date of the earliest claim to priority, whether any other patent in the priority chain issued and when.

Continuation practice has a number of pernicious consequences, which we detail in Part II. First, at a minimum, continuation practice introduces substantial delay and uncertainty into the lives of a patentee's competitors, ${ }^{6}$ who can never know whether a patent application is pending. Second, the structure of the PTO suggests that continuations may well succeed in "wearing down" the examiner, so that the applicant obtains a broad patent not because he deserves one but because the examiner has neither incentive nor will to hold out any longer. Third, continuation practice can be - and has been - used strategically to gain advantages over competitors by waiting to see what product the competitor will make and then drafting patent claims specifically designed to cover that product. Finally, some patentees have used continuation practice to delay the issuance of their patent precisely in order to surprise a mature industry, a process known as "submarine patenting."

Congress and the courts have in turn created a number of patent doctrines designed to combat the misuse of continuation applications. In the last ten years, they have changed the term

\footnotetext{
${ }^{6}$ Original applications take on average 1.96 years from their filing to issuance. Continuations, in contrast, take on average 4.16 years. See infra notes ____ and accompanying text.
} 
of patents, ended the secrecy of most patent applications, revived the controversial doctrine of written description, and created an entirely new defense of prosecution laches, all in an effort to deal with abuses of the continuation process. While these changes have indeed mitigated some of the worst abuses of the continuation process, our data demonstrate that they are not likely to be effective in tackling the core of the problem.

One simple solution to the problems that beset continuations would be to abolish the practice. Part III explores this alternative. In it, we consider the various justifications that have been offered for continuation practice and find many of them wanting. We also consider various complicating factors and potential down-sides to abolishing continuations. We conclude from our empirical research that while there are very real abuses of the system which can be attributed to continuation practice, they may not be so widespread as to justify eliminating continuation practice entirely. As alternatives to this drastic remedy, we offer a number of other steps that Congress and the courts could take to restrict abuse of continuations, including requiring publication of all applications, putting a time limit on the addition of new claims that broaden the scope of the patent, and creating a defense for infringers who independently developed the patented invention before it was added to the patent claims. At a bare minimum, our data should enable the courts to add some rigor to the new doctrine of prosecution laches by providing a baseline against which to judge the reasonableness of any particular patentee's delay.

\section{The Curious Practice of Continuing Patent Applications}

\section{A. How the System Works}

In order to obtain a patent, an inventor must persuade the PTO that her invention meets the requirements of the patent statute. The inventor files an application, which is examined by 
the PTO in a process called “patent prosecution.” The application contains a written description of the invention and concludes with a number of "claims" that define the scope of the invention. ${ }^{7}$ The inventor must also disclose any "prior art" - other patents or publications that might anticipate the invention - of which she is aware, though she has no duty to search for prior art. ${ }^{8}$ The prosecution process is ex parte: only the inventor and the patent examiner participate in the decision whether to issue a patent.

The actual process of prosecution is a back-and-forth affair between the applicant and the examiner. Once the inventor files her application, the examiner reviews the application for compliance with the statute and conducts a brief search for prior art. ${ }^{9}$ Based on this analysis, the examiner may decide to allow the claims of the patent as filed. ${ }^{10}$ More likely, the examiner will

735 U.S.C. §112. Claims define the scope of the invention, just as a real property deed defines the "metes and bounds" of a real property right. See, e.g., Regents Of University Of New Mexico v. Knight, 321 F.3d 1111, 1122 (Fed. Cir. 2003). Unlike land, however, inventions are difficult and perhaps even impossible to define clearly in words. See Festo Corp. v. Shoketsu Kinzoku Kogyo Kabushiki Co., 535 U.S. 722, 731 (2002) ("the nature of language makes it impossible to capture the essence of a thing in a patent application"); Craig Allen Nard, A Theory of Claim Interpretation, 14 HARV. J. L. \& TECH. 1 (2000). The imprecision of words is further substantiated by the high rate of reversals of claim construction determinations. See, e.g., Kimberly A. Moore, Are District Court Judges Equipped to Resolve Patent Cases?, 15 HARV. J. L. \& TECH. 1 (2001) (demonstrating that the Federal Circuit overturned district court claim constructions in 33\% of the cases); Christian A. Chu, Empirical Analysis of the Federal Circuit’s Claim Construction Trends, 16 BERKELEY TECH. L.J. 1075 (2001) (same).

837 C.F.R. § 1.56.

9 Because of the substantial backlog of cases at the PTO, it often takes a year or more after the application is filed before it is first examined.

The PTO does not always have access to prior art, and examiners have very little time to search for and analyze the prior art. As a result, the examination is far from perfect. See, e.g., Mark A. Lemley, Rational Ignorance at the Patent Office, 95 Nw. U. L. REV. 1495 (2001). One empirical study found that the PTO missed a significant percentage of cases in which two or more inventors applied for a patent on an identical invention, the sort of prior art they should be particularly likely to discover. Mark A. Lemley \& Colleen V. Chien, Are the U.S. Patent Priority Rules Really Necessary?, 54 HASTINGS L.J. _ (forthcoming 2003). For anecdotal discussion of the failure of the PTO to find relevant prior art, see, e.g., Jay Kesan \& Marc Banik, Patents as Incomplete Contracts: Aligning Incentives for R\&D Investment With Incentives to Disclose Prior Art, 2 WASH. U. J. L. \& POL'Y 23 (2000); Robert P. Merges, As Many As Six Impossible Patents Before Breakfast: Property Rights for Business Concepts and Patent System Reform, 14 BERKELEY TECH. L.J. 577 (1999).

10 First-action allowances are sufficiently rare that patent attorneys generally feel that if they get one, it means they haven't asked for broad enough claims. See, e.g., KinNEy \& LANGe, P.A., InTELlECtUAl Property LAW FOR BUSINESS LAWYERS §3.4.3 (2003 Update) ("Patent attorneys generally do not like to have applications allowed when they are first submitted. Such first-action allowances often indicate that the attorney drafted the claims too 
issue a rejection of one or more claims in the application, often based on similarity to the prior art or failure to describe the invention in significant detail. The applicant will respond to this rejection by trying to persuade the examiner that he is wrong, by disclosing information or a declaration showing that the invention is patentable, or by amending the claims of the patent to narrow them and avoid the prior art. The examiner then reviews this response to the office action, and may either allow the patent claim or issue what is called a "Final Rejection" of the application.

The term "Final Rejection" is a classic legal misnomer. ${ }^{11}$ An applicant faced with a final rejection has several options. First, she can request a face-to-face or telephonic interview with the examiner. ${ }^{12}$ Unlike the rest of the prosecution history, which involves written correspondence and is therefore carefully documented, the interview is not transcribed and the interview summary which will be completed by the examiner is often cryptic and uninformative. ${ }^{13}$ It is quite common for an examiner to withdraw a final rejection and allow the claims after such an interview. Second, the applicant may choose to appeal the rejection to the Board of Patent Appeals and Interferences and, if she loses there, to the U.S. District Court for the District of Columbia or to the U.S. Court of Appeals for the Federal Circuit. ${ }^{14}$

narrowly and that they could have received more protection for the invention. In fact, some attorneys will try for broader protection for the invention by filing continuation applications if they receive a first-action allowance.”).

11 See Robert P. Merges et al., Intellectual Property in the New Technological Age 116 (3d ed. 2003) (“The label 'final rejection' is a misnomer if ever there was one.”).

12 On this procedure, see 37 C.F.R. § 1.133(b) (2002).

13 M.P.E.P. \$711.06 explains that examiners must fill out interview summaries to be included in the prosecution history if they meet with the applicant. In our experience, however, this "interview summary" is rarely more than a sentence and often says nothing more than "Claims 1-11 are in condition for allowance."

14 See 35 U.S.C. § 134 (Board appeals); § 141 (Federal Circuit appeals); §145 (District Court for the District of Columbia appeals). An applicant who loses before the Board may appeal to the United States District Court for the District of Columbia rather than the Federal Circuit, but the appeal from the district court would then be to the Federal Circuit. §145. 
Alternatively, the applicant may choose to start the prosecution process over by filing a continuation application. Under section $120,{ }^{15}$ an applicant can file such a continuation application at any time before the PTO actually issues the patent or before the applicant abandons the application. Continuations are commonly filed after a final rejection, but they are sometimes filed after allowance as well, either because the applicant wants the allowed claims to issue but also wants to argue for broader claims to be included in later patents, or because the applicant decides to abandon the allowed claims and try for broader claims instead. When a continuation application is filed, the prosecution process we have just described starts over. The continuation application is treated just like a new application, giving the applicant another set of chances to persuade the examiner to allow the claims, to further amend the claims, or even to hope to get a different examiner. ${ }^{16}$ If none of this works, the applicant can file yet another continuation application, and so on ad infinitum. There is no way an examiner can ever cause a determined applicant to go away, though allowing the applicant's patent claims will increase the chance that the case will finally be disposed of.

\section{B. The Use of Continuation Practice}

Continuations are widely used in today's patent system. The results of our comprehensive study of patent continuations shows that twenty-three percent of all patents granted from 1976 through 2000 claim priority to one or more earlier filed applications. Although there has been some fluctuation over the years in the number of continuation patents

1535 U.S.C. $\S 120$.

16 Examiner turnover is notoriously high because of the low salaries and high workloads at the PTO. See, e.g., Merges, Impossible Patents, supra note _, at 606-07. 
filed, the trend has been a steady increase. In the mid-1970s, about one-fifth of all issued patents were based on continuations. ${ }^{17}$ By the mid-1990s the number of continuation patents that issued climbed to 31\%. That number has declined somewhat in the last several years, in part because of changes in the way patent term is calculated,$^{18}$ but it remains at about one-quarter of all issued patents. Continuations are a major part of patent practice. They are especially important in certain industries, particularly pharmaceuticals and biotechnology. ${ }^{19}$ In those industries, most patent lawyers with an important application will try to keep at least one continuation application pending in the PTO well after a patent issues so that they can track changes in the marketplace. ${ }^{20}$

The effect of these continuations is substantial. Recent work by Cecil Quillen et al. show that when continuations are taken into account, the PTO issues patents on over $85 \%$ of the application chains that are filed. ${ }^{21}$ Patents that issue from continuation applications, or from

\footnotetext{
${ }^{17}$ In 1976, 1977, 1978, and 1979 the percentage of issued patents that were continuations was 23\%, 22\%, 21\%, and $21 \%$, respectively.

18 See infra notes ____ and accompanying text.

19 See John R. Allison \& Mark A. Lemley, Who's Patenting What? An Empirical Exploration of Patent Prosecution, 53 VAND. L. REV. 2099, 2125 \& 2154 Table 9 (2000) (finding that while the average patent in 1996-98 issued from 1.50 applications, the average pharmaceutical patent issued from 2.27 applications, and the average biotechnology patent from 2.38 applications).
}

20 See, e.g., Harold Wegner, The End of Equivalents? Examining the Fallout From Festo, 13 FordHAm InTELL. Prop., Media \& ENT. L.J. 727, 742 (2003) ("you take whatever claims you can, you file a continuation with a disclaimer, and then you keep that new case pending forever and ever and ever, and then you add claims when you need them. Now, that is not a very good public policy. But, it is something that is an effective way to deal with the problem. We do it all the time.”).

21 Cecil D. Quillen Jr. et al., Continuing Patent Applications and Performance of the U.S. Patent and Trademark Office - Extended, 12 FED. CIR. BAR J. 35, 38 (2002). Quillen and Webster had originally estimated in earlier work that the grant rate was 95\%. Cecil D. Quillen Jr. \& Ogden H. Webster, Continuing Patent Applications and Performance of the U.S. Patent and Trademark Office, 11 FED. CIR. BAR J. 1 (2001). This earlier work was properly criticized for failing to take account of continuation practice. On the other hand, some of the critics made equally unrealistic assumptions - for example, that every continuation filed results in a separate patent. See Robert A. Clarke, U.S. Continuity Law and its Impact on the Comparative Patenting Rates of the US, Japan and the European Patent Office, 85 J. PATENT \& TRADEMARK OfC. SoC’y 335, 338 (2003) (wrongly making this assumption and concluding that the grant rate was $75 \%$ ). The $85 \%$ number in the revised Quillen study is based on actual data about the applications that issue based on continuations, and reflects the best estimate we have of how often applications mature into patents. 
families in which continuations are filed, are also substantially more likely to be litigated than patents that issue directly from original applications. ${ }^{22}$ While continuations are filed in $23 \%$ of all patent applications, patents based on continuation applications represent 52\% of all litigated patents. Although continuations are used in a minority of all patents, it is the most important minority because it is the minority most likely to end up in litigation. ${ }^{23}$ Figure 1 shows the time spent in prosecution (from earliest priority date to issuance) for issued and litigated patents.

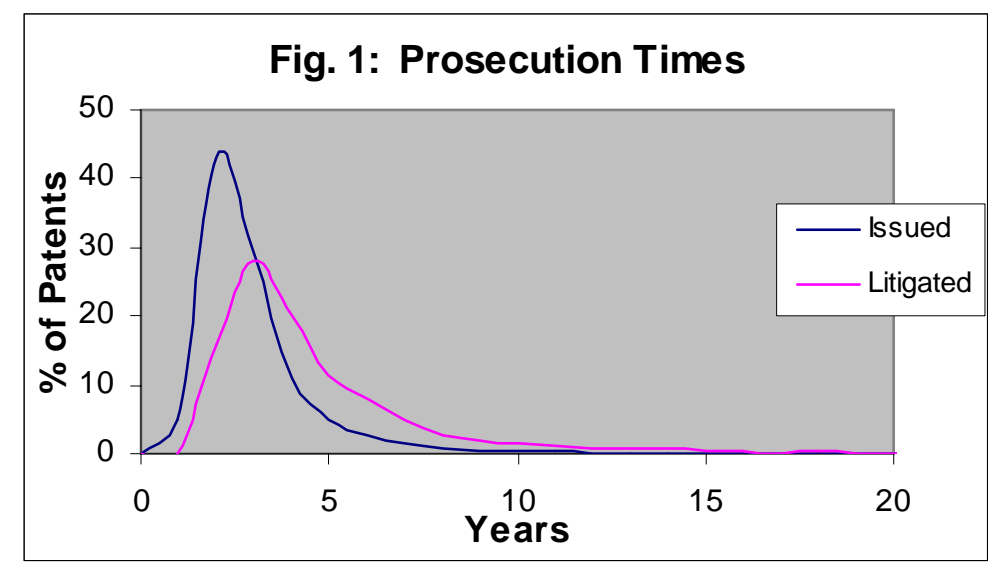

\section{What's Wrong with Continuation Applications}

While it is certainly odd to an outsider that the PTO has no power to ever terminate a patent prosecution, the fact that a rule looks odd is not necessarily a reason to do away with it. This is particularly true in patent law, which has no shortage of odd rules. ${ }^{24}$ Continuation practice, however, has a number of pernicious consequences for the patent system. Those harmful consequences fall into four categories.

22 See John R. Allison et al., Valuable Patents, 92 GEO. L.J. _ (forthcoming 2004) (finding that litigated patents filed more than three times as many continuation applications as non-litigated patents, and also came from substantially larger families of patents).

23 See Allison et al., Valuable Patents, supra note __, at _ (explaining that litigated patents are a subset of all valuable patents).

24 To take just one example, the United States Supreme Court has held that a single individual wearing underwear (beneath her clothing) is engaged in "public use" of that underwear barring a patent, but that a road in central Boston traversed by people for six years was not in public use. Compare Egbert v. Lippmann, 104 U.S. 333 (1881) with City of Elizabeth v. Pavement Co., 97 U.S. 126 (1877). 


\section{A. Delay and Uncertainty}

Continuations take time. Even if the patentee does not intend to delay the issuance of a patent, ${ }^{25}$ starting the prosecution process over naturally adds significantly to the time a patent application spends in prosecution. During the period of our study, prosecution took 2.47 years on average from the earliest claimed filing date to issuance date. Figure 2 below plots the time applications spent at the PTO by year in terms of their application time (time from its filing date to issuance) and their prosecution time (time from their earliest claim of priority to issuance). As Figure 2 indicates the mean time patent applications spend at the PTO is on the rise in recent years. In fact, the application time reached the highest point in 2000 in the 25 years of the study. The prosecution time (time from earliest claim of priority) has risen even more dramatically in recent years due to the increase in the number of continuation patents. ${ }^{26}$ Original patent applications that issue take 1.96 years on average to issue, while patents with at least one continuation take 4.16 years on average to issue. Indeed, some patent prosecutions with multiple continuations take decades to make it out of the PTO. ${ }^{27}$ For example, U.S. patent No. 5,966,457 claimed priority to twenty-one different applications and its total prosecution spanned more than

${ }^{25}$ On intentional delay, see infra notes _ _ _ and accompanying text.

${ }^{26}$ Figure 1 shows the increase in mean years spent in prosecution. This increase is attributable to increased use of continuation practice. See supra note 17 and accompanying text.

${ }^{27}$ Of course, there are a few original patent applications that take decades to issue as well, but this is due to secrecy restrictions, interferences, Board, district court or Federal Circuit appeals. See, e.g., U.S. Patent No. 5,132,080 (an original application was filed November 28, 1944 and the patent was not permitted to issue until July 21, 1992 due to secrecy restrictions); U.S. Patent No. 6,097,812 (filed July 25, 1933 and delayed due to secrecy until August 1, 2000); U.S. Patent No. 6,130,946 (filed October 23, 1936 and delayed due to secrecy until October 10, 2000). Pursuant to 35 U.S.C. §181, the Commissioner of the PTO must withhold the granting of any patent "[w]henever publication or disclosure ... by the grant of a patent on an invention in which the Government has a property interest might, in the opinion of the head of the interested Government agency, be detrimental to the national security.” Id. Although $\S 181$ only permits the Commissioner to delay patent issuance for up to one year, the secrecy can be renewed for an unlimited number of one year periods if it is in the interest of national security. Id. 
forty-four years. Table 1 in the Appendix shows the distribution of patents as measured by the length of their prosecution from their earliest claim to priority to their issuance. ${ }^{28}$

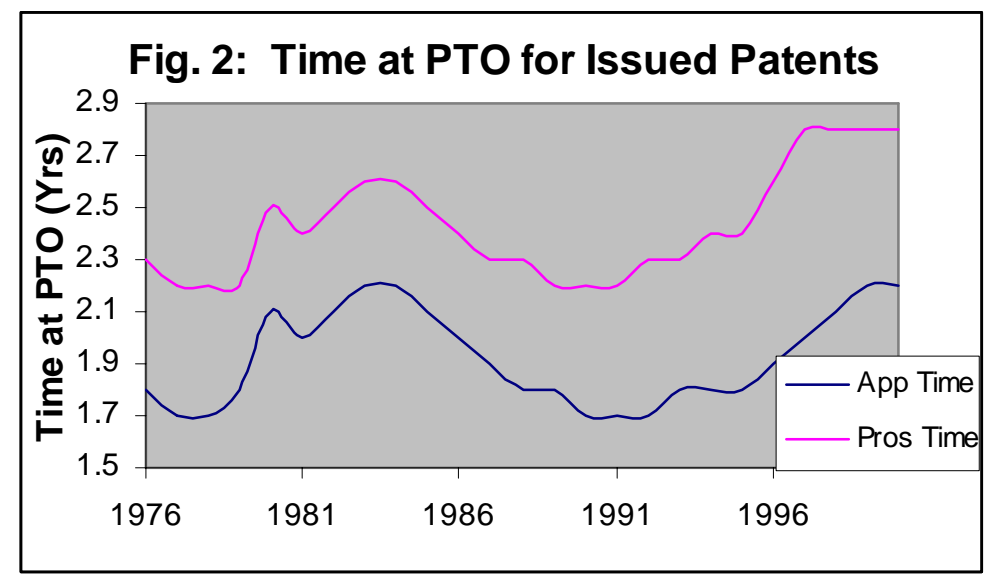

Moreover, continuation applications themselves do not take significantly less time to prosecute than original applications. Intuitively, one might think that the examination time ought to decrease with each continuation since the examiner is, in theory, already familiar with the application, the prior art, and the applicant's claims. This intuition is not accurate. Patents based on one or more continuations take on average 1.86 years from the filing date of the continuation to the grant date. Patents with no earlier claims to priority (original applications) take on average 1.96 years from filing date to grant date-just 36 days longer. The fact that there is negligible efficiency associated with continuation examination - that prosecution takes no less time the second time around - could be due to examiner turn-over, heavy examiner caseloads ${ }^{29}$ or merely

\footnotetext{
${ }^{28}$ The earliest claim to priority is measured as the earliest claim to a related application on the front face of the patent. This would include continuations (\$120), continuations-in-part (\$120) and divisionals (§121). It does not include foreign claims to priority under $\$ 119$ or PCT claims (priority claims based upon the Patent Cooperation Treaty). Foreign priority claims under $\S 119$ could delay prosecution up to one additional year and PCT claims could delay prosecution another thirty months.

${ }^{29}$ See, e.g., John R. Thomas, The Question Concerning Patent Law and Pioneer Inventions, 10 HigH TECH. L.J. 35, 100 (1995) (referring to examiners as "notoriously overworked”); Simson Garfinkel, Patently Absurd, WIRED, July 1994, at 104; Eugene R. Quinn, Jr., The Proliferation of Electronic Commerce Patents: Don't Blame the PTO, 28 Rutgers Comp. \& TECH. L.J. 121, 122 (2002); Flavio Rose, Patent Truths, L.A. LAW., Oct. 2001, at 40.
} 
a function of the small number of hours that examiners spend on each application over the course of several years. ${ }^{30}$

The delays caused by continuation practice create significant uncertainty among competitors. Patent applications filed before 2000 were kept secret unless and until they issued as patents. As a result, competitors could not know whether patent applications were pending that might cover their products. The passage of time might reduce the risk that a patent would be issued covering a particular technology, but it could never eliminate that risk. Indeed, Stuart Graham has theorized that the use of continuations may be valuable to patentees precisely because it permits them to maintain secrecy while simultaneously benefiting from patent protection. $^{31}$

\section{B. Wearing Down the Examiner}

Prosecutions involving one or more continuations are more complex than other sorts of prosecutions. $^{32}$ The applicant spends more time before the PTO, and the examiner has more chances to evaluate the application and the prior art. This might be a good thing; if the examiner has more time to spend with an application, we might expect him to do a better job in deciding

30 Although it varies by technology, examiners spend on average eighteen hours on each patent application from start to finish. Lemley, Rational Ignorance, supra note _, at 1496 n.3. In this eighteen hours, the examiner must review the patent application, conduct a search of the prior art, compare the prior art to the claims sought and issue at least one and usually more office actions either allowing or rejecting the claims. When examiners only spend eighteen hours on applications and that eighteen hours is spread over nearly two years, it is not surprising that a continuation takes almost as much time as the original application.

31 Stuart J.H. Graham, Hiding in the Patent's Shadow: Firms' Use of Secrecy to Capture Value from New Discoveries (working paper 2002).

32 See John R. Allison \& Mark A. Lemley, The Growing Complexity of the U.S. Patent System, 82 B.U. L. Rev. 72 (2002) (finding that patents that issue from continuation applications also tend to include more claims, cite more prior art, spend more time in the PTO and have more inventors than patents that issue from the initial application). 
whether to issue it as a patent. $^{33}$ The key question is whether a more extensive patent prosecution translates into a more rigorous evaluation of the application by the PTO. There are reasons to be skeptical. Patent examiners have notoriously heavy caseloads, ${ }^{34}$ and they are rewarded only for an initial response to a patent application and for finally disposing of a case. ${ }^{35}$ As a result, an examiner has no incentive to spend more time on harder cases; quite the contrary. ${ }^{36}$ There is reason to worry, therefore, that patents with multiple claims and lots of prior art will get less, not more, attention paid at the PTO to each claim or piece of prior art. An applicant's ability to file continuation applications and draw the process out even further exacerbates the problem. Because an examiner can only finally dispose of an application by allowing it, an examiner faced with a determined applicant has every incentive to give in and allow the patent. ${ }^{37}$ This is particularly likely since the patents that involve the most continuation

33 Allison \& Lemley call this the "patent value” theory - important patents are worth a more rigorous examination. Id. at 139-41. By contrast, it does not make sense to subject all applications to a rigorous examination. Lemley, Rational Ignorance, supra note _, at 1495.

34 See, e.g., John R. Thomas, The Question Concerning Patent Law and Pioneer Inventions, 10 HIGH TECH. L.J. 35, 100 (1995) (referring to examiners as “notoriously overworked”); Simson Garfinkel, Patently Absurd, WIRED, July 1994, at 104; Eugene R. Quinn, Jr., The Proliferation of Electronic Commerce Patents: Don't Blame the PTO, 28 Rutgers Comp. \& TeCH. L.J. 121, 122 (2002); Flavio Rose, Patent Truths, L.A. LAW., Oct. 2001, at 40.

35 For a full discussion of the difficulties with the examiner incentive system, see John R. Thomas, Collusion and Collective Action in the Patent System: A Proposal for Patent Bounties, 2001 U. ILL. L. REV. 305, 324; Robert P. Merges, As Many as Six Impossible Patents Before Breakfast: Property Rights for Business Concepts and Patent System Reform, 14 Berkeley TeCH. L.J. 577 (1999); Arti K. Rai, Addressing the Patent Gold Rush: The Role of Deference to PTO Patent Denials, 2 WASH. U. J. L. \& POL’y 199, 218 (2000).

36 Data do suggest that the PTO takes longer to issue more complex applications. A simple OLS regression showed that the number of claims and prior art references cited significantly impacted the time it took to prosecute applications. However, in each case, the impact was slight (each additional claim beyond the mean of 12.47 increases prosecution time by 1.66 days and each additional US patent prior art reference cited above the mean of 7.83 increases prosecution 2.08 days). It does not follow, however, that examiners spend more time reviewing those applications. They may simply put off the hardest tasks, concentrating first on applications that are easier to dispose of. Cf. David Popp et al., Time in Purgatory: Determinants of the Grant Lag for U.S. Patent Applications (working paper) available at http://www.nber.org/papers/w9518 (examining the patent characteristics which impact grant lag).

37 See Allison et al., Valuable Patents, supra note _ _, at _. Allison et al. suggest that the PTO should change its internal processes to enable examiners to spend more time on such applications. 
applications tend to be those with more claims and more prior art than average - that is, the very patents the examiner least wants to see again. ${ }^{38}$

If continuation applications permit the applicant to wear down the examiner, obtaining a patent that the PTO would otherwise refuse to grant, they give applicants with dubious claims to ownership intellectual property rights that they can enforce against the world. It is inevitable that the PTO will make mistakes. ${ }^{39}$ But continuation applications may be more likely than average to result in bad patents. This is a particular problem for society because our empirical evidence suggests that patents based on continuation applications are far more likely to be litigated than other sorts of patents. ${ }^{40}$ As a result, mistakes in issuing continuation patents are much more likely to impose social costs than mistakes with other sorts of patents.

\section{Changing Claims}

While some applicants file continuation applications in order to have a further opportunity to persuade the PTO to issue the claims they originally sought, others file continuation applications in order to have an opportunity to modify their claims. Applicants might want to modify their claims after filing for a variety of reasons. Some are innocuous - the applicant may simply have drafted the claims poorly in the first instance and want a second chance at drafting claims of appropriate scope. Other explanations are more problematic,

Some commentators have suggested to us that Examiners might actually prefer continuation applications, since they have already learned the technology and can get disposal credits without having to do as much work. The long delay associated with continuation applications belies that claim; it scarcely seems credible that an Examiner will remember enough about a case nearly two years after she last dealt with it to result in a significant time savings.

38 Allison et al., Valuable Patents, supra note _, at _.

39 See Lemley, Rational Ignorance, supra note _, at 1495.

40 Although $23 \%$ of all issued patents are continuations, 52\% of all litigated patents are continuations. 
however. Inventors can keep an application pending in the PTO for years, all the while monitoring developments in the marketplace. They can then draft claims that they can be sure will cover those developments. ${ }^{41}$ In the most extreme cases, patent applicants add claims during the continuation process to cover ideas they never thought of themselves, but instead learned from a competitor. ${ }^{42}$ The most egregious example is Jerome Lemelson, who regularly rewrote claims over the decades his patents were in prosecution in order to cover technologies developed long after he first filed his applications. ${ }^{43}$ Lemelson filed eight of the ten continuation patents with the longest delays in prosecution in our study. Those Lemelson patents spent anywhere from thirty-eight to more than forty-four years in the PTO. ${ }^{44}$

The Federal Circuit has made it clear that the law permits the drafting of claims written during prosecution specifically in order to cover a competitor’s products. In Kingsdown Medical Consultants v. Hollister, ${ }^{45}$ the court explained:

41 See, e.g., MERGES ET AL., supra note _, at 116 ("patent lawyers often file a continuation application just prior to the issuance of a patent, so that prosecution based on the original disclosure may continue. This is valuable where a competitor may attempt to design around a patent by adopting minor variants. In that event, it may be possible to revise the continuation application claims to cover the competitor's new variant, considerably enhancing the effective scope of the patent.”).

42 For example, in Chiron Corp. v. Genentech, Inc., 2002 WL 32124007 (E.D. Cal. June 24, 2002), the plaintiff filed a patent application covering monoclonal antibodies in 1984, at a time when the technology was in its infancy. It kept various applications pending in the PTO until 1999, when it drafted new claims designed to cover not just monoclonal antibodies as they were understood in 1984, but new types of antibodies developed in the intervening 15 years, including those invented by the defendant. And the patentee in Gentry Gallery v. Berkline Corp., 134 F.3d 1473 (Fed. Cir. 1998) amended its claims to a reclining chair to claim placing the controls for that chair in a position it never thought of, but saw for the first time on its competitor's product. Id. at 1479 ("Sproule admitted at trial that he did not consider placing the controls outside the console until he became aware that some of Gentry's competitors were so locating the recliner controls.”).

43 For discussion of Lemelson's patent tactics, see James W. Morando \& Christian H. Nadan, Silent Enemies, RECORDER, May 4, 1994, at 10.

44 Some of Lemelson's patents and their delays are as follows: 5,966,457 (21 related applications, 44.33 years in prosecution), 5,570,992 (30 related applications, 42.28 years in prosecution), 5,491,591 (8 related applications, 40.67 years in prosecution), 5,351,078 (12 related applications, 39.76 years in prosecution), 5,283,641 (11 related applications, 39.11 years in prosecution), 5,281,079 (29 related applications, 39.50 years in prosecution), and 5,249,045 (10 related applications, 38.76 years in prosecution).

45863 F.2d 867 (Fed. Cir. 1988). 
It should be made clear at the outset of the present discussion that there is nothing improper, illegal or inequitable in filing a patent application for the purpose of obtaining a right to exclude a known competitor's product from the market; nor is it in any manner improper to amend or insert claims intended to cover a competitor's product the applicant's attorney has learned about during the prosecution of a patent application. Any such amendment or insertion must comply with all statutes and regulations, of course, but, if it does, its genesis in the marketplace is simply irrelevant and cannot of itself evidence deceitful intent. $^{46}$

To be sure, applicants do not simply have carte blanche to rewrite their claims. The new claims must find adequate support in the original application. If not, the patent will be invalid for lack of written description, ${ }^{47}$ or alternatively the new claims will be considered "new matter" invented only as of the date the claims were added. ${ }^{48}$ But if the patentee can find some support in the original patent application for the current claims, they can obtain legal rights over ideas that (at least in that form) never occurred to them until they saw what others were already doing.

It makes some sense for the law to permit correction of claim drafting errors. Words are notoriously imperfect at defining inventions. ${ }^{49}$ But we do not need continuation practice in order to achieve this goal. A patentee dissatisfied with her claims can rewrite those claims in a reissue proceeding. ${ }^{50}$ A patentee may seek a reissue at any time to narrow her claims or within two years

\footnotetext{
46 Id. at 874. Accord State Indus., Inc. v. A.O. Smith Corp., 751 F.2d 1226, 1235 (Fed.Cir.1985).

47 This was the fate of the claim changes in Gentry Gallery and Chiron. Gentry Gallery v. Berkline Corp., 134 F.3d 1473 (Fed. Cir. 1998) (court found claim invalid for lack of written description); Chiron Corp. v. Genentech, Inc., 2002 WL 32124007 (E.D. Cal. June 24, 2002) (jury found claims invalid for lack of written description; district court refused to overturn jury verdict).

4835 U.S.C. $\S 132(a)$.

49 See Festo Corp. v. Shoketsu Kinzoku Kogyo Kabushiki Co., 535 U.S. 722, 731 (2002) ("the nature of language makes it impossible to capture the essence of a thing in a patent application.”); Craig Allen Nard, A Theory of Claim Interpretation, 14 HARV. J. L. \& TECH. 1 (2000).

5035 U.S.C. $§ 251$.
} 
of the original issue date if she wishes to broaden them. ${ }^{51}$ In addition, the doctrine of equivalents exists to prevent a patent owner from losing effective protection because she did not draft claims that effectively cover what she invented. ${ }^{52}$ That doctrine permits a patentee to argue that an accused infringer's device should be adjudged infringing even though it does not literally fit within the language of the claims because the differences between the claims and the accused device are "insubstantial." 53 Together, these doctrines are sufficient to solve any legitimate problems with poorly drafted claims.

Permitting patentees to change claims to track competitor's products invites abuse of the system. $^{54}$ It seems fundamentally unfair, since even a competitor who was legitimately the first to invent a particular device or process may be held to have infringed on a patent claim written after (and indeed because of) that invention. It also seems inconsistent with the fundamental economic justification for the patent system, which is to encourage new inventions. As commentators have noted, the patent system must balance between encouraging pioneering inventions and encouraging improvements. ${ }^{55}$ Strategic claim changes may hold up legitimate improvers or independent inventors, reducing their ability and incentive to innovate.

51 Id.

52 See, e.g., Graver Tank \& Mfg. Co. v. Linde Air Prods., 339 U.S. 605 (1950).

53 See Hilton Davis Chem. Co. v. Warner Jenkinson Co., 62 F.3d 1512 (Fed. Cir. 1995) (en banc), rev'd on other grounds, 520 U.S. 17 (1997).

54 On the general problem of abusive intellectual property litigation entered into in order to hold up competitors, see Michael J. Meurer, Controlling Opportunistic and Anticompetitive Intellectual Property Litigation, 44 B.C. L. REV. 509 (2003).

55 See, e.g., Robert P. Merges \& Richard R. Nelson, On the Complex Economics of Patent Scope, 90 CoLUM. L. REV. 839, 843 (1990); Suzanne Scotchmer, Standing on the Shoulders of Giants: Cumulative Research and the Patent Law, 5 J. ECON. PERSP. 29, 30 (1991). (noting difficulties in the optimal allocation of rights between pioneers and improvers); Mark A. Lemley, The Economics of Improvement in Intellectual Property Law, 75 TEX. L. REV. 989 (1997). 


\section{Submarine Patents}

A related problem to changing claims is intentional delay in the issuance of patents designed to take a mature industry by surprise. A number of patentees have used the continuation process to delay the issuance of their patents indefinitely. By doing so, they obtain a patent that may be more valuable than one that issued in the early stages of a new industry. This value may come from the growth of the market over time: the broad patents the Wright Brothers obtained on aircraft would presumably bring in more revenue if in force today than they did 100 years ago. $^{56}$ Alternatively, the value may come from the ability to capture specific investments made by competitors who assumed with the passage of time that a technology was in the public domain. Once a semiconductor company has invested $\$ 2-4$ billion in a new fab, ${ }^{57}$ it will be willing to pay more for the right to use that fab than if approached for a license ex ante. ${ }^{58}$ Intentional delay to increase the value of the resulting patent is referred to as "submarine patenting” because the patents surface unexpectedly and take competitors by surprise.

Submarine patenting depends heavily on continuation practice. Without the ability to abandon and refile applications an unlimited number of times even in the face of a decision by

56 On the Wright Brothers patents and their litigation, see AM. HeRITAGE InVEnTION \& TECH., Summer 2003, at 一.

57 See Mark LaPedus, Leading Edge Fab Costs Soar to \$4 Billion, http://www.siliconstrategies.com/story/OEG20030310S0067 (March 10, 2003) (estimating cost of a next-generation semiconductor fab at \$4 billion); Steve Lohr, World-Class Chip, but a Fragile Business, N.Y. TIMES, Aug. 4, 2003, at C1 (noting that fabs cost $\$ 2-3$ billion each).

58 This is not simply because the semiconductor company doesn't understand the economic concept of sunk costs, though surprisingly few people do. Before investment, the semiconductor company likely faces a choice of alternative technologies, and the value of a patent on one of those alternatives is constrained by the ability to choose the other. Once a large investment has been made in using the patented technology, by contrast, it will often become uneconomic to switch to the other technology. As a result, the patentee will have substantial bargaining power if the patent is not disclosed until after the investment has been made.

An analogous problem arises where patent owners withhold information from standard-setting organizations in an effort to encourage that investment. See Patterson, supra note __; Mark A. Lemley, Intellectual Property Rights and Standard-Setting Organizations, 90 CALIF. L. REV. 1889 (2002). 
the PTO to allow the patent, submarine patentees like Jerome Lemelson would not be able to delay the issuance of their patents. Submarine patenting also depended significantly on two other long-standing rules in U.S. patent law that have now been modified: the fact that a patent, once issued, lasted for 17 years from the date of issue regardless of when it was filed, and the fact that applications were kept secret until they issue as patents. Secrecy permitted submarine patents to surprise the industry, and the invariability of patent term meant that the patentee didn’t give up any protection by delaying issuance of the patent. Both of these rules changed in the 1990s. Congress changed the patent term in 1994 from 17 years from issue to 20 years from the filing of the first application. ${ }^{59}$ As a result, every year a patentee delays prosecution of its application is a year of protection lost. And in 1999, Congress required publication of many (though not all) patent applications 18 months after the application is filed. This makes secrecy of submarine patents difficult to maintain. While these legislative changes have significantly ameliorated the problem of submarine patents for applications filed after 1995, they have not eliminated the problem entirely, however, as we discuss below.

There is no social benefit whatever to submarine patents. They extend the effective life of patents, permit patentees to hold up competitors who have made investments in plant capacity, and upset the settled expectations of manufacturers in a variety of industries. They do nothing to encourage innovation, and indeed on net they probably discourage it. ${ }^{60}$ Abolishing continuations would make it far more difficult to engage in submarine patenting. ${ }^{61}$

\footnotetext{
5935 U.S.C. § 154(a)(2).
}

60 It is true that transferring revenues to a patentee will increase the reward to patenting. But it will not necessarily support innovation. It may instead support the activities of "inventors" like Jerome Lemelson, whose primary focus was in drafting patents rather than promoting the progress of the useful arts.

61 Submarine patentees might delay issuance of patents by provoking interferences (administrative trials between two or more applicants who claim to have invented the same thing) or by using the internal PTO appeals process rather than continuations to challenge rejections. But both approaches are risky, because they may result in a loss of 


\section{E. Evergreening}

A final problem with continuation applications is that they can result in multiple patents covering the same invention. Patentees regularly use continuation applications not just to fight repeatedly for the issuance of a single patent, but to obtain a narrow patent relatively quickly while continuing to argue for a broader one. ${ }^{62}$ Of the more than two million patents in our dataset, $23.3 \%$ claim priority to one or more earlier filed applications and $42.3 \%$ of these patents with earlier claims of priority had at least one other patent in the chain issue. ${ }^{63}$ Continuation applications are an important part of this practice, because they permit a patentee to claim the same priority date for both patents, avoiding having one patent serve as prior art invalidating the other. ${ }^{64}$ This practice is known as "double patenting," and the law has evolved a complex set of rules to deal with it. Stripped to its essence, the rule is that a patentee cannot obtain two or more patents that cover precisely the same thing. ${ }^{65}$ A second patent that covers precisely the scope of the first is invalid for double patenting, even if they stem from the same application. By contrast, if the second patent is not precisely the same as the first, but covers an invention that would be

all patent rights and because the patentee will have an adversary arguing against patentability. And unlike continuations, the loser in an appeal or interference can't simply refile to try again.

62 See Wegner, supra note _ (suggesting that patentees do this “all the time”); MERGES ET AL., supra note _, at 116 ("Typical prosecution strategy is to take the bird in the hand and fight over the contested claims separately.").

${ }^{63}$ The Quillen et al. study found that 31\% of the patents that issued based on a continuation application also had a patent issue from the parent application. Quillen et al., supra note _ , at 38. Quillen was based on a sample of only 1000 patents, while the data presented in this study is all 2,224,379 issued patents from 1976-2000. Cf. Allison et al., Valuable Patents, supra note _, at _ (observing that while patents in general had on average only 0.22 "relatives" - other patents issued from applications in the same family chain - each, litigated patents had 0.85 relatives each on average).

64 An issued patent can invalidate a subsequently filed application if it issues more than a year before the new application is filed, see 35 U.S.C. § 102(b).

65 See supra note _ (discussing the rules of double patenting). 
obvious (and therefore unpatentable) in view of the first, the rule is different. The doctrine of "obviousness-type double patenting" permits the grant of two or more patents to the same inventor, ${ }^{66}$ but requires that the patents expire on the same day in order to prevent the extension of patent rights beyond the lawful term of the first patent. ${ }^{67}$ The law has traditionally accomplished this by having the patentee disclaim part of the term of the second patent, ${ }^{68}$ but with the shift to a patent term measured from the first filing date the problem will generally take care of itself.

While the doctrine of obviousness-type double patenting solves the worst problem with obtaining multiple patents, double patenting still has pernicious consequences in the pharmaceutical industry. Under the Hatch-Waxman Act, a pharmaceutical patent-owner is entitled to list its patents with the FDA in the "Orange Book."69 A generic company that wants permission from the FDA to make a drug covered by a patent in the Orange Book must certify that the patent is invalid or that it will not infringe the patent. ${ }^{70}$ If it does so, the patent owner can sue the generic for infringement and obtain an automatic 30-month stay preventing the generic from entering the market. ${ }^{71}$ Pharmaceutical patent owners have used the continuation process to obtain multiple patents covering obvious variants of the same drug, and have listed

66 If inventorship is not the same, but overlapping, two different patents are generally treated as unrelated. An important exception is 35 U.S.C. § 103(c), which was amended in 1984 to provide that if different inventors work for the same company, their unpublished inventions will not be prior art against each other for purposes of finding the later invention obvious.

67 In re Goodman, 11 F.3d 1046 (Fed. Cir. 1993).

68 Ortho Pharmaceutical v. Smith, 959 F.2d 936, 940 (Fed. Cir. 1992) (“Unlike 'same-invention’ double patenting, obviousness-type double patenting can be overcome by filing a terminal disclaimer.”).

6921 U.S.C. § 355(j)(7)(A)(iii) (2000). For a good overview of the provisions of the Hatch-Waxman Act, see Thomas F. Cotter, Refining the "Presumptive Illegality" Approach to Settlements of Patent Disputes Involving Reverse Payments, 87 MinN. L. REV. 1789 (2003).

7021 U.S.C. § 355(j)(2)(A)(vii)(IV) (2000).

7121 U.S.C. $\S 355(j)(2)(B)(i i i)$. 
each of those patents in the Orange Book at different times. ${ }^{72}$ The result has been that the pharmaceutical company can obtain not one, but many sequential 30-month stays. This practice is known as "evergreening."73 It serves no useful social purpose, and reflects a rather blatant gaming of the Hatch-Waxman rules for pharmaceutical patents.

Evergreening is facilitated by the existence of continuation applications. While it would be possible to engage in evergreening without using continuations, it would be much more difficult, since the patentee would have to file multiple applications on the same day, but manage to draw one prosecution out much longer than another without using continuations. Abolishing continuations would help end the practice. There may be other ways to solve the problem, however. Evergreening has been challenged as an antitrust violation, though courts generally have not been receptive to these claims. ${ }^{74}$ Legislation pending in Congress at this writing would close the Hatch-Waxman loophole by requiring that patentees obtain no more than one 30-month stay per product, no matter how many patents they list in the Orange Book. ${ }^{75}$ Such statutory or antitrust solutions would be largely unnecessary if continuations were abolished, however.

\section{F. Indirect Efforts to Solve the Problem of Continuations}

\footnotetext{
72 See, e.g., In re Biovail Corp., 2002 WL 727033, Dock. No. 0110094 (FTC April 23, 2002) (consent decree settling antitrust charges related to sequential listing of patents covering Tiazac in the Orange Book); 2 HERBERT HOVENKAMP ET AL., IP AND ANTITRUST §33.9 (2003) (discussing cases involving this practice).

73 See, e.g., Lara J. Glasgow, Stretching the Limits of Intellectual Property Rights: Has the Pharmaceutical Industry Gone Too Far?, 41 IDEA 227 (2001); Christine S. Paine, Brand Name Drug Manufacturers Risk Antitrust Violations By Slowing Generic Production Through Patent Layering, 33 SETON HALL L. REV. 479, 506 (2002); Frederick Tong, Widening the Bottleneck of Pharmaceutical Patent Exclusivity, 24 WHITTIER L. REV. 775, 787-88 (2003).

74 See Paine, supra note _ _ at 507 (noting that evergreening involves petitioning the government for patent rights, and so is likely to be protected from antitrust scrutiny by Noerr immunity).

75 Greater Access to Affordable Pharmaceuticals Act of 2002, S. 812, $108^{\text {th }}$ Cong., $1^{\text {st }}$ Sess. S. 812 passed the Senate in July, but no action has been taken in the House. See http://www.leydig.com/News/raf_sep2002.asp.
} 
The abuse of continuation practice has led to a number of legislative and judicial efforts to solve the problem by indirect means. Congress has changed the patent term, required that patent applications be published before they issue, and is considering changing the HatchWaxman rules for pharmaceutical patent litigation. The Federal Circuit has created an entirely new doctrine (prosecution history laches) and revived another (the written description doctrine). The Patent and Trademark Office is considering a proposal to change the way it charges fees in order to discourage the filing of multiple continuation applications. All this was done in order to combat some of the evils of continuation applications. This section briefly reviews those legal changes. We note that they have not been completely effective in preventing abuse of continuation practice, and that the new doctrines in turn create problems of their own. It is also important to note that approximately 1.3 million issued patents in the dataset were filed before the term change and could still be in force today with a term seventeen years from issuance. ${ }^{76}$ Suffice it to say that despite the legal changes we describe here, there remains both a large pool of potential submarine patents still in force to be concerned with and continued potential for abuse of the continuation process in new applications.

\section{Changing the Patent Term}

\footnotetext{
76 Since patents may expire because their owners fail to pay their maintenance fees, and indeed approximately twothirds of all patents eventually do so, see Lemley, Rational Ignorance, supra note _, at 1500, there are no accurate calculations presently available for the number of enforceable patents at any given time. While we can calculate the number of patents filed before June 7, 1995 which have yet to expire due to term end, and can therefore get an idea of the maximum number of potentially enforceable patents (one million three hundred thousand), we cannot calculate the exact number of them that are still enforceable or the number of potential submarine patents in that group. One of the authors, however, is currently studying patents that expire due to failure to pay maintenance fees and what can be learned from them. Kimberly A. Moore, Worthless Patents (in progress).
} 
The adoption of the twenty-year patent term for applications filed beginning in $1995^{77}$ reduces the incentives to extend prosecution through continuation practice. Under pre-1995 law, a patent was given seventeen years of protection regardless of how long it took to obtain. Because the new patent term is measured twenty years from the date the first application is filed, applicants who spend significant time in prosecution lose an equivalent amount of time from the patent term. ${ }^{78}$ This reduces the incentive to engage in long-duration continuation practice, and eliminates entirely the incentive to continue an application for more than twenty years.

While the patent term change undoubtedly reduces the incentive to submarine patent, continuation practice has continued to be problematic. A recent study by Graham and Mowery finds that the use of continuations rose from approximately $12 \%$ of all applications in the late 1980s to 30\% of all applications by the mid-1990s. By the late 1990s, after the patent term changed, the number of continuations had fallen somewhat to $20 \%$, but was still well above its historic levels. ${ }^{79}$ Some of the problems that remain are transition issues. The 20-year patent term applies only to applications filed after June $7,1995 .^{80}$ And indeed there was a rush to file applications before that deadline. ${ }^{81}$ As discussed earlier, there could be as many as 1.3 million issued, enforceable patents that exist under the old patent term. Those patents will slowly dwindle over time.

\footnotetext{
7735 U.S.C. $§ 154(\mathrm{a})(2)$.

78 The statement in text is no longer entirely accurate. Congress changed the law in 1999 to give back some patent term where the PTO was responsible at least in part for the time spent in prosecution. 35 U.S.C. § 154(b). But it is nonetheless true that applicants get less protection the more time they spend in prosecution.

79 Graham \& Mowery, supra note _, at Figure 1.

80 Pub. L. No. 103-465 (1994). Applications filed or patents in force before June 7, 1995 are entitled to the longer of the two term options. Any continuations or divisionals filed after June 7, 1995 have the term twenty years from earliest claimed filing date. See M.P.E.P. §2701.
}

81 See Allison \& Lemley, Who’s Patenting What?, supra note _, at 2119 \& n.66 (documenting this effect); Quillen, et al., supra note _, at 39-42, Figs. 1-4 (documenting the spike in filings in 1995). 
Even beyond the transition period, submarine patenting can be expected to continue. While an applicant faced with the twenty-year term would not have any incentive to delay her prosecution twenty years or more, since she would lose the entire period of exclusivity, a patentee may well have an incentive to sacrifice, say, ten years of patent term in order to capture an industry by surprise. This is particularly true in industries such as pharmaceuticals or biotechnology, where the main economic value of a patent comes late in the patent, after FDA approval. $^{82}$ The PTO has several means of categorizing an invention according to its technological field. Broadly, all inventions are classified into Technology Centers (of which there are seven), more narrowly, inventions are classified into a technology class (of which there are 464) and within technology classes there are further levels of subclassification. ${ }^{83}$ Table 2 demonstrates the frequency of continuation practice varies by PTO Technology Center with the highest percentage of continuations filed in the Biotechnology and Chemical areas. Table 2 also shows the corresponding delay in prosecution caused by these continuations. ${ }^{84}$

Table 2: Continuation Filing By Technology Center

\begin{tabular}{|c|c|c|c|}
$\begin{array}{c}\text { Tech } \\
\text { Center \# }\end{array}$ & Tech Center & $\begin{array}{c}\text { \% of } \\
\text { Continuations }\end{array}$ & $\begin{array}{c}\text { Length of } \\
\text { Prosecution (Yrs) }\end{array}$ \\
\hline
\end{tabular}

82 See, e.g., Allison et al., Valuable Patents, supra note _ surprising that patentees in those industries are particularly likely to use continuation applications.

83 We recognize that the PTO’s classification system is far from perfect for delineating inventions by technology. For example, there is no single technology class or center that contains all software, rather software inventions may be found in many different classes. For criticisms of the PTO's technology classifications system see Allison et al., Valuable Patents, supra note _ _, at _ (explaining that the PTO classification system was "never intended to provide conceptual delineations of technology areas, but instead identify inventions by function at very low levels of abstraction in order to serve as aids to prior art searching”). In an ideal world, we would classify each patent by hand into the proper area of technology. With a database of over two million patents, of course, that is unrealistic. The reader should be aware that the broad technology classes we discuss here do not map perfectly to actual industry boundaries.

${ }^{84}$ While length of prosecution is affected by continuation practice, it is also affected by technology class, number of claims, number prior art references, etc. See infra notes ____ and accompanying text (discussing the factors that impact length of prosecution). 


\begin{tabular}{|c|l|c|c|}
\hline 1600 & Biotechnology and Organic Chemistry & $43 \%$ & 3.34 \\
\hline 1700 & Chemical and Materials Engineering & $30 \%$ & 2.54 \\
\hline 2100 & $\begin{array}{l}\text { Computer Architecture, Software, and } \\
\text { Information Security }\end{array}$ & $25 \%$ & 2.17 \\
\hline 2600 & Communications & $18 \%$ & 2.28 \\
\hline 2800 & $\begin{array}{l}\text { Semiconductors, Electrical and Optical } \\
\text { Systems and Components }\end{array}$ & $15 \%$ & 2.20 \\
\hline 3600 & $\begin{array}{l}\text { Transportation, Construction, Electronic } \\
\text { Commerce, Agriculture, National Security }\end{array}$ & $20 \%$ & 2.21 \\
\hline & $\begin{array}{l}\text { Mechanical Engineering, Manufacturing, } \\
\text { and Products and Designs }\end{array}$ & & \\
\hline
\end{tabular}

Another reason why the twenty-year term will not eliminate abuse of continuations is that a patent applicant who obtains a patent in order to hold up a mature industry may not be as concerned about the length of the exclusion right as they are about taking the industry by surprise. For such a patentee, it may be worth foregoing some years of royalties if they can coerce licensing payments from companies who have already made asset-specific investments in the technology that is ultimately patented. ${ }^{85}$ In addition, the ability of a patentee to obtain an early patent in a quick prosecution and also to keep a continuation application pending means that the patentee need not forego all protection during the period the continuation application is pending, but could enforce the narrow patent while waiting to issue a broad one. ${ }^{86}$

85 For a discussion of co-specific assets that correlate with inventions and which companies can appropriate, see David J. Teece, Profiting from Technological Innovation: Implications for Integration, Collaboration, Licensing and Public Policy, 15 Res. Pol'y 285, 288-90 (1986). For a more specific example of how such asset-specific investments can facilitate holdup by patent lawyers, see Mark R. Patterson, Inventions, Industry Standards, and Intellectual Property, 17 BERKELEY TeCH. L.J. 1043 (2002) (noting that patent owners can demand a higher royalty rate once their inventions have been incorporated in industry standards).

86 Patent law does forbid so-called double-patenting, at least where the two patents claim the identical invention. General Foods Corp. v. Studiengesellschaft Kohle mbH, 972 F.2d 1272 (Fed. Cir. 1992) ("the same invention cannot be patented more than once"; noting that otherwise "a second patent . . . would expire some time after the original patent and extend the protection timewise.”).

Patent law also restricts the patenting of obvious variants on an existing invention under the judiciallycreated doctrine of "obviousness-type double patenting." In re Goodman, 11 F.3d 1046 (Fed. Cir. 1993). Interestingly, the obviousness-type double patenting rules developed in ways that punished applicants who 
While the twenty year term measured from filing date does help minimize submarine patenting or at least limits the amount of time these patents can stay under, it does not eliminate the harmful impact of the surprise on the maturing industry of a patent whose owner intentionally delays at the PTO. Moreover, if the twenty year term were absolute it would disadvantage some innocent applicants whose prosecutions are delayed for legitimate grounds or through no fault of their own. Responding to this concern, Congress created exceptions to the twenty-year term that permit patent term choice, ${ }^{87}$ restorations of lost term, ${ }^{88}$ adjustments in the calculation of patent term, ${ }^{89}$ and extensions of patent term. ${ }^{90}$ The result is that you cannot tell when a patent expires without complicated patent term calculation and resort to the patent's prosecution history. These deviations from the twenty-year term may further reduce its effectiveness in dealing with abuse of the continuation process.

\section{Publishing Patent Applications}

A second legislative attempt to control submarine patenting is the new requirement that patent applications be published 18 months after they are filed. ${ }^{91}$ Publishing pending

intentionally delayed prosecution, but not those whose prosecution was delayed because of PTO mistakes. Compare In re Emert, 124 F.3d 1458 (Fed. Cir. 1997) with In re Braat, 937 F.2d 589 (Fed. Cir. 1991). Because obviousnesstype double patenting can be cured by disclaiming the period of protection after the expiration of the first patent, Ortho Pharmaceutical v. Smith, 959 F.2d 936 (Fed. Cir. 1992), it no longer has much relevance since the patent term was changed to run twenty years from the filing of the first application.

${ }^{87}$ Any patent filed before June 7, 1995 and still pending gets the longer of the two patent terms. See supra note _.

${ }^{88} 35$ U.S.C. $§ 155 A$ (providing for patent term restoration where the FDA stayed approval of the patented product inhibiting the patentee's utilization of their exclusive patent term).

8935 U.S.C. §154(b) (providing for adjustment in patent term where delays are attributable to the PTO). There are even appeal procedures for disputes regarding the appropriate amount of patent term adjustment. See id.

9035 U.S.C. $\$ 155$ (providing for patent term extensions where the FDA stayed approval of the patented product inhibiting the patentee's utilization of their exclusive patent term); 35 U.S.C. \$156 (providing for patent term extensions when a product covered by the patent claims has been subject o regulatory review).

9135 U.S.C. $\S 122(\mathrm{~b})$. 
applications in theory reduces uncertainty, since it gives competitors an opportunity to find out who has pending patent applications. In practice, however, the anemic publication rules in the U.S. patent law are unlikely to have much effect. The 18-month publication rule was significantly weakened by Congress before it was passed in 1999. The statute requires publication only of those applications that will also be filed abroad. ${ }^{92}$ Because the rest of the world already required publication 18 months after filing, ${ }^{93}$ the U.S. publication requirement will result in little or no increase in the information that is published. Applications that were already published abroad will now be published in the U.S. as well, but applications that were not filed or published abroad need not be published in the U.S. either. ${ }^{94}$ Because many submarine patentees are individuals who do not file abroad, ${ }^{95}$ they will not be deterred by the 18 -month publication rule. Further, our data show that individual domestic inventors, who are least likely to patent abroad, are the most common users of the continuation system. There are 854 patents that took twenty years or longer in prosecution, see Table 1, and twenty six percent of these patents issued to U.S. individuals. ${ }^{96}$

9235 U.S.C. § 122(b)(2)(B)(i). Indeed, the statute provides that you don’t have to publish any material you aren’t already obligated to publish abroad. Id. $\S 122(\mathrm{~b})(2)(\mathrm{B})(\mathrm{v})$. Thus, it essentially adds nothing to what was already being published outside the United States. Moreover, design patents, provisional applications, and applications no longer pending (abandoned or not issued) are not published. Id.

93 See, e.g., Charles R. McManis, Intellectual Property, Genetic Resources, and Traditional Knowledge Protection: Thinking Globally, Acting Locally, 11 CARDOZO J. INT'L \& COMP. L. 547, 565 n.85 (2003) (discussing "the requirement in most national patent systems that patent applications be published eighteen months after they have been filed").

94 Early evidence from the PTO suggests that most applications are being published, presumably including some that are not also filed abroad. [cite $88 \%$ statistic from PTO Web site]. But the abusers of continuation practice those who engage in submarining or changing claims - will have an incentive to avoid publication.

95 For example, none of the fifty patents with the longest delays claim priority to any foreign filings. Foreign filings may have been made after the U.S. patent filing, however, a possibility which our dataset does not allow us to determine.

96 By contrast, U.S. individuals obtain only eighteen percent of all issued patents. 
Even for those applications that are published, the fact that the patent has not issued means that competitors still face significant uncertainty. A competitor can find out that an application is pending, but cannot know for sure whether a patent will issue, ${ }^{97}$ and until the patent issues what the scope of its claims might be. ${ }^{98}$ Moreover, even if publication of the original application occurs, it requires significant effort to get access to the ongoing prosecution record. ${ }^{99}$ Hence, publication will not solve the problem of changing claims to track competitors. If the patentee changes claims over time, those changes may take the market by surprise even if competitors read the published applications. ${ }^{100}$ Publication is also limited in scope: there is no publication of provisional applications, ${ }^{101}$ design patents, ${ }^{102}$ applications subject to secrecy or applications that are no longer pending.

Further, while publication provides competitors with an opportunity to see what applications are pending, it does not necessarily follow that competitors will take advantage of that opportunity. There are strong incentives for competitors not to read patents or published patent applications. Reading a patent puts a company on notice of possible infringement,

97 To be sure, it's a pretty good bet that the patent will ultimately issue. Quillen et al. demonstrate that the PTO issues patents on about $85 \%$ of the application chains it receives, far more than the European or Japanese patent offices. Quillen et al., supra note _, at 38.

98 Patent claims are often amended during prosecution, see RoBERT P. MERGES \& JoHN F. DufFy, PATENT LAW AND POLICY 51 (3d ed. 2002), and one of the reasons to file a continuation application is to get a change to argue for different claims than those in the original application. See supra notes __-_ and accompanying text.

99 The PTO has "laid open" the patent prosecution at its offices in Virginia, but does not publish the prosecution history of pending applications or make the information available electronically. The only way to obtain such information is to show up at the PTO and request it.

100 Many of the patents with the longest delays did, in fact, have a relative in the chain of priority issue at some point during prosecution. While this would give the public assess to the specification of the patent that issued including the written description and the claims, the public has no way of knowing that the applicant would later seek broader claims. The issuance of a patent in the chain with narrow claims, like the publication of an application with narrow claims, can actually mislead the public.

101 See 35 U.S.C. §111(b) (defining provisional applications).

102 See 35 U.S.C. $\$ 161$ (defining design patents). 
triggering an obligation to pay for an expensive written opinion of counsel or risk treble damage liability and attorneys' fees as a willful infringer. ${ }^{103}$ Companies often advise their employees not to read patents; ${ }^{104}$ even if this is good advice it plays into the hands of submarine patentees.

\section{Increased Use of the Written Description Requirement}

In recent years, the Federal Circuit has attempted to curtail abusive continuation practice judicially by strengthening the written description requirement. ${ }^{105}$ Section 112 requires that a patent contain a written description of the invention the applicant seeks to claim. ${ }^{106}$ For continuation applications, the originally filed specification must meet the section 112 written description requirement for the newly filed claims. The purpose of this requirement is to ensure that the applicant possessed the invention and made this possession clear in her original specification in order to be entitled to claim priority to an earlier application. In circumstances where the original application does not disclose the invention sought to be claimed in the continuation application, those continuation claims are invalid for failing to satisfy the written description requirement. ${ }^{107}$ In the main, the written description requirement exists to combat

\footnotetext{
103 For more on this remarkable doctrine, see Matthew D. Powers \& Steven C. Carlson, The Evolution and Impact of the Doctrine of Willful Patent Infringement, 51 SYR. L. REV. 53 (2001); Lemley \& Tangri, supra note

104 Companies often advise their scientists not to read patents at all, for fear of being determined to be willful infringers. See, e.g., Mark A. Lemley \& Ragesh K. Tangri, Ending Patent Law’s Willfulness Game, 18 Berkeley Tech. L.J. _ (forthcoming Fall 2003). Applicants may have an incentive to put competitors on notice of published patent applications as soon as possible, however, because they will then be able to take advantage of a right to collect pre-issuance royalties from those who copied the published applications. 35 U.S.C. § 154(d)(1).

105 See, e.g., Brian Wm. Higgins, Note Reiffen and the New Economy: Rethinking the Use of the Written Description Requirement to Curb Submarine Patent Tactics, 11 FED. CircuIT B.J. 23, 24-25 (2001) (arguing that although the written description requirement has become "the latest weapon against these so-called submarine patent tactics," "the test is fraught with imperfection, and adds confusion rather than clarity to the submarine patent problem”).

10635 U.S.C. $\$ 112$.

107 See, e.g., The Gentry Gallery Corp. v. The Berkline Corp., 134 F.3d 1473 (Fed. Cir. 1998) (claims added during prosecution to read on competitors device invalid for failing to satisfy the written description requirement); Hyatt $\mathrm{v}$.
} 
continuation abuse. The focus of the doctrine on claims changed during prosecution is consistent

with a desire to eliminate one of the core harms of continuation practice, the drafting of new claims designed to capture inventions first made by competitors. The Federal Circuit has also expanded the written description requirement beyond continuation cases limits by holding that even originally filed claims could also fail the written description requirement, at least in the biotechnology field. ${ }^{108}$ The strengthening and evolution of the written description requirement has been criticized as incoherent. ${ }^{109}$ It seems to narrow the scope of patent claims, and provides a powerful new weapon to those seeking to invalidate patents, particularly patents issued before the mid-1990s, when the doctrine was rejuvenated.

Boone, 146 F.3d 1348, 1352 (Fed. Cir. 1998) (holding that when seeking to rely on an earlier filing date the earlier application must satisfy the written description requirement); Amgen, Inc. v. Hoechst Marion Roussel Inc., 314 F.3d 1313, 1330-31 (Fed. Cir. 2003); Cooper Cameron Corp. v. Kvaerner Oilfield Prods., 291 F.3d 1317 (Fed. Cir. 2002).

108 See, e.g., Janice M. Mueller, The Evolving Application of the Written Description Requirement to Biotechnological Inventions, 13 BERKELEY TECH. L.J. 615, 652 (1998) (noting that "the Lilly decision... reflect[s] an increasingly-widening gulf between the norms of the business and scientific community and those of the United States patent system"); Harold C. Wegner, When a Written Description Is Not a "Written Description": When Enzo Says It's Not, 12 FED. CIR. B. J. 271 (2002). Regents of the University of California v. Eli Lilly \& Co., 119 F.3d 1559, 1568 (Fed. Cir. 1997) (holding originally filed biotechnology claims invalid for failing to satisfy the written description requirement); Enzo Biochem v. Gen-Probe, Inc., 323 F.3d 956, 968 (Fed. Cir. 2002) (holding that the written description requirement can even invalidate originally filed biotechnology claims). For criticism of the court's extension of written description to DNA cases, see Jeffie A. Kopczynski , A New Era for 112? Exploring Recent Developments in the Written Description Requirement as Applied to Biotechnology Inventions, 16 HARV. J. L. \& TECH. 229, 261 (2002) (“The written description requirement is now in a state of flux.”); Dan L. Burk \& Mark A. Lemley, Is Patent Law Technology-Specific?, 17 BeRKeLEY TECH. L.J. 1155 (2002); Arti K. Rai, Intellectual Property Rights in Biotechnology: Addressing New Technology, 34 WAKE FOREST L. Rev. 827, 834- 35 (1999); Margaret Sampson, The Evolution of the Enablement and Written Description Requirements Under 35 U.S.C. \& 112 in the Area of Biotechnology" 15 BERKELEY TECH. L.J. 1233, 1262 (2000). For an argument that this expansion of the written description requirement is limited to biotechnology cases, see Dan L. Burk \& Mark A. Lemley, Policy Levers in Patent Law, 89 VA. L. REV. _ (forthcoming December 2003).

109 For criticism of the written description doctrine as applied to changed claims, see, e.g., Moba, B.V. v. Diamond Automation, Inc., 325 F.3d 1306, 1327-28 (Fed. Cir. 2003) (Bryson, J., concurring) (suggesting that written description is unnecessary as a way of dealing with claim changes); Kopczynski, supra note _, at 230 (suggesting that the new written description requirement is "unduly rigid"); Harris A. Pitlick, The Mutation on the Description Requirement Gene, 80 J. PAT. \& TRADEMARK OfF. SOC'Y 209, 222 (1998) (calling the doctrine "an unmitigated disaster"); Laurence H. Pretty, The Recline and Fall of Mechanical Genus Claim Scope Under 'Written Description' in the Sofa Case, 80 J. PAT. \& TRADEMARK OfF. SOC’y 469 (1998). The written description requirement might still play a role in cases in which a patentee changed its claims to cover a competitor's technology during the initial prosecution period, without filing a continuation. Because the time elapsed is shorter, however, that is less likely to happen than claim changes that occur during prosecution of a continuation application. 
Even if the written description requirement was a predictable and coherent doctrine, it would do nothing to solve several of the continuation-based abuses such as wearing down the examiner, surprising industry, or extending one's monopoly. The only continuation-based abuse that could be addressed by strong written description requirement is the filing of broader claims in a continuation to read on a competitor's device that the earlier specification did not clearly disclose. Written description is therefore at best only a partial solution to the problem of continuation abuse.

\section{New Prosecution Laches Defense}

The Federal Circuit created a new defense to patent infringement (or more precisely revived a dormant one $)^{110}$ in 2002. Called "prosecution laches," the defense renders unenforceable patents that spent an unreasonable amount of time in prosecution, ${ }^{111}$ and permits the PTO to reject applications that have been unreasonably delayed by the applicant. ${ }^{112}$ The new prosecution laches defense may help function as a catch-all to ultimately render unenforceable those submarine patents that either were not eliminated through other reform efforts or were filed before the reforms went into effect. It is hardly an optimal solution, however. Leaving until litigation the certainty of a patent's term and a patentee's behavior during prosecution is a worstcase solution to the continuation problem. Litigation is expensive, time consuming, and

\footnotetext{
110 The defense was only recently endorsed by the Federal Circuit as a valid grounds for challenging the enforceability of a patent. We call it a revived defense, however, because the Federal Circuit held that prosecution laches is a viable defense based on Supreme Court precedent nearly 80 years in age. Symbol Techs. v. Lemelson, 277 F.3d 1361 (Fed. Cir. 2002) (validating the defense). Of course, the Federal Circuit had itself in several nonprecedential decisions indicated that there was no such defense. See Bott v. Four Star Corp., 1988 WL 54107 (Fed. Cir. 1988) (unpublished decision); Ricoh Co. v. Nashua Corp., 1999 WL 88969 (Fed. Cir. 1999) (unpublished decision); Ford Motor Co. v. Lemelson, 124 F.3d 227 (Fed. Cir. 1997) (unpublished decision).

111 Symbol Technologies, 277 F.3d at 1361.

112 In re Bogese, 303 F.3d 1362 (Fed. Cir. 2002).
} 
uncertain. ${ }^{113}$ At present, no district court has held that the prosecution laches defense ought to apply, despite delays of as much as thirteen years during patent prosecution. ${ }^{114}$ The hesitancy of the district courts to utilize this defense may be attributable to the difficulty in assessing the reasonableness of the delay, a problem which our empirical study can help eliminate. We discuss our data on the reasonableness of continuation delays in the next Part. ${ }^{115}$

\section{Eliminating Continuation Applications}

The doctrines we described in the last part are helpful in containing some of the worst abuses. But they do not solve the problem of continuation abuse altogether, and they come with their own costs and they are efforts to address the problem indirectly. Instead, we consider solving the problem directly by eliminating continuation applications altogether.

Eliminating continuation applications is the obvious solution to the manifold abuses of the system. But is it the right solution? In this part, we consider the likely effects of abolition. We begin by examining the justifications that have been offered by patentees and scholars in support of continuation applications, and find those arguments generally wanting. While there is some risk that abolishing continuation applications will weaken the value of patents, the weakening that is most likely to occur is in the anticompetitive "holdup" value of a small subset of patents. Weakening the power of patentees to hold up true innovators is a feature of abolition, not a bug. Second, we consider some complications that arise from the many different forms continuation practice can take. Any proposal to eliminate continuations and continuation-in-part

\footnotetext{
${ }^{113}$ See American Intellectual Property LaW Association, Report of ECONOMiC SurVey 2001, at 84-85 (demonstrating that the median litigation expenses for a patent case are $\$ 1.5$ million per side).

114 All the district courts to rule on the issue have found no laches because the time involved was not unreasonable. See infra note

115 See infra notes ___ and accompanying text.
} 
applications should not extend to divisional applications. Eliminating continuations altogether would not eliminate all abuses of the patent prosecution system. But it would certainly restrict those abuses, and eliminate the worst elements.

While abolishing continuation practice would address many of the concerns we have about abuse of the patent system, our empirical research convinces us that such a solution is likely overkill. There are a few inventors who are severely abusing continuation practice. Those abuses are spotlighted because the inventors who abuse the system are more likely to litigate their patents. We determine, however, that the abuse, while severe, is narrow in scope. As Table 1 demonstrates, only a few patents issued with particularly lengthy prosecutions based upon numerous continuations. Moreover, we recognize the political realities that would likely prevent Congress from abolishing continuation practice. Accordingly, we propose several interim measures that can be used to help solve the problem if continuations remain a part of the patent landscape.

\section{A. Justifications for Continuation Applications}

Why do patentees file continuation applications? By and large, the benefits to patent applicants of filing continuations track the social harms discussed in the last section. Three such justifications can be disposed of easily. Patent applicants have historically used continuations to extend the effective life of their patents, to avoid having to disclose their technology too early, and to change claims in order to cover their competitors' products. ${ }^{116}$ It is easy to see why patentees would want to do these things; they are likely to enhance the value of the patent. But they are all things that society has a strong interest in preventing. Patent law reflects a series of

116 See supra notes ____ and accompanying text (discussing these uses in detail). 
bargains and compromises between the patentee, subsequent inventors, and the public. Patents must disclose the claimed invention in sufficient detail that others can make and use it; patents that do not provide such disclosure are invalid. ${ }^{117}$ The disclosure requirement is imposed in order to give the public the ability to make and use the invention once the patent expires, and to design around the patent while it is in force. ${ }^{118}$ Similarly, the patent term is limited so that the public may make use of the invention after a certain time without having to pay a royalty; ${ }^{119}$ efforts to extend that time are illegal per se. ${ }^{120}$ And patent law divides entitlements between initial inventors and subsequent improvers, permitting the initial inventor to capture the value of 11735 U.S.C. § 112 ๆ 1.

118 On the value of disclosure to the public as part of the patent bargain, see R. Polk Wagner, Information Wants to be Free: Intellectual Property and the Mythologies of Control, 103 Colum. L. REv. 995, 1007 n.46 (2003); David J. Teece \& Edward F. Sherry, Standards Setting and Antitrust, 87 MinN. L. REV. 1913, 1964 (2003). The classical explanation is that disclosure of an invention permits the public to use it once the patent expires.

Disclosure serves another purpose as well - it permits competitors to design around the invention, creating a non-infringing product even while the patent is in force. On the social value of design-arounds, see, e.g., WarnerJenkinson Co. v. Hilton Davis Chem. Co., 520 U.S. 17, 36 (1997) (contrasting "the intentional copyist making minor changes to lower the risk of legal action" with "the incremental innovator designing around the claims, yet seeking to capture as much as is permissible of the patented advance"); see also Slimfold Mfg. Co. v. Kinkead Indus., Inc., 932 F.2d 1453, 1457 (Fed. Cir. 1991) (Rich, J.) ("Designing around patents is, in fact, one of the ways in which the patent system works to the advantage of the public in promoting progress in the useful arts, its constitutional purpose.”); State Indus. v. A.O. Smith Corp., 751 F.2d 1226, 1236 (Fed. Cir. 1985) (“One of the benefits of a patent system is its so-called 'negative incentive' to 'design around' a competitor's products, even when they are patented, thus bringing a steady flow of innovations to the marketplace.”); Craig Allen Nard, $A$ Theory of Claim Interpretation, 14 HARV. J.L. \& TECH. 1, 40-41 (2000) ("The practice of designing-around extant patents creates viable substitutes and advances, resulting in competition among patented technologies. The public clearly benefits from such activity.”); Matthew J. Conigliaro et al., Foreseeability in Patent Law, 16 BERKELEY TECH. L.J. 1045, 1050-51 (2001) ("Unlike copyists, who merely mimic a device and add nothing to the public body of knowledge, those who invent new devices by intentionally designing around a patent nonetheless advance the public welfare and fulfill the purpose of the Patent Clause.”).

119 A number of economists have attempted to derive the optimal patent term by balancing the incentives created by patent protection against the social value of permitting the public to practice the invention after expiration. See, e.g., William D. Nordhaus, InVEnTION, GROWTH, AND WelFare 76-86 (1979); F.M. Scherer, Nordhaus' Theory of Optimal Patent Life: A Geometric Reinterpretation, 62 AM. ECON. ReV. 422, 424 (1972); Louis Kaplow, The Patent-Antitrust Intersection: A Reappraisal, 97 HARV. L. Rev. 1813, 1817 (1984); John F. Duffy, Deriving the Optimal Patent Term (working paper 2003). Cf. Richard Gilbert and Carl Shapiro, Optimal Patent Length and Breadth, 21 RAND J. ECON. 106, 111 (1990) (suggesting that optimal patents might be extremely long but quite narrow); Ian Ayres \& Paul Klemperer, Limiting Patentees' Market Power Without Reducing Innovation Incentives: The Perverse Benefits of Uncertainty and Non-Injunctive Remedies, 97 MicH. L. REV. 985 (1999) (suggesting that society would benefit from longer patent terms coupled with less powerful remedies).

120 Brulotte v. Thys, 379 U.S. 29 (1964); see generally HERBERT HOVENKAMP ET AL., IP AND ANTITRUST §§3.3b3, 23.2 (2002). 
an improver's technology only in limited circumstances. ${ }^{121}$ These compromises are an integral part of the balance the patent law strikes between encouraging innovation and promoting the use and dissemination of new technology. ${ }^{122}$ Continuation practice permits patentees to undo this balance, benefiting them privately but hurting society as a whole.

The patent statute strikes a balance between changing claims and stopping holdups through reissue practice, which permits patentees to broaden their claims within two years after the patent issues. ${ }^{123}$ Reissue practice already leaves competitors with a zone of uncertainty, but at least with reissue, the zone has a definitive end - two years from issuance, a competitor can be certain the claim scope will not be expanded. Continuation practice makes this zone of certainty boundless.

A fourth reason patentees use continuation practice is more ambiguous in effect. Patentees often file continuations not to try to game the system but in order to continue fighting for claims they believe themselves entitled to, but which examiners refuse to grant. These patentees are trying to obtain in good faith coverage they believe they are entitled to under the patent system. Continuation practice gives them multiple opportunities to persuade the PTO to grant their claims, and to refine their claims to make sure they are effective. But it is not clear that granting unlimited such opportunities is good for society as a whole. Patent examiners have

121 For discussion of the division of profit between initial inventors and subsequent improvers, see Jerry R. Green \& Suzanne Scotchmer, On the Division of Profit in Sequential Innovation, 26 RAND J. ECoN. 20, 22 (1995) (suggesting that profit should be weighted toward initial inventors); Scotchmer, supra note _ (noting tradeoff); Merges \& Nelson, supra note __; Lemley, Economics of Improvement, supra note _ (both suggesting importance of balance between initial inventors and improvers).

122 See MERGES ET AL., supra note _, at 15 ("the economic incentive benefits of intellectual property rights must be balanced against the costs of limiting diffusion of knowledge.”).

12335 U.S.C. $\S 251$. 
strong incentives to allow contested patent claims rather than continuing to fight. ${ }^{124}$ Permitting a patent applicant to file an unlimited number of continuations has the effect of "wearing down" the examiner, inducing the PTO to issue patents because they are sick of fighting rather than because the application deserves a patent. ${ }^{125}$ The risk of issuing bad patents is a reason not to permit patentees to argue indefinitely for broad claims. ${ }^{126}$ And it is worth noting that even abolishing continuations would not leave these patentees without recourse. The patent application process includes a provision for appeal to the Board of Patent Appeals and Interferences, and from there to the U.S. Court of Appeals for the Federal Circuit or the U.S. District Court for the District of Columbia. ${ }^{127}$ This appeal process, not continuation practice, is the way the patent system was intended to handle fights over patentability.

Despite the existence of an appeal process, there is some risk that without continuation practice patent applicants will not obtain claims of sufficiently broad scope to effectively protect their invention, and that this could reduce incentives to innovate. ${ }^{128}$ We think that risk is counterbalanced by several countervailing factors, however. First, the effective scope of patents

124 See supra note __ (discussing these incentives).

125 For a discussion of the problem of “wearing down” examiners, see Allison et al., Valuable Patents, supra note — at _.

126 Mark Lemley has argued elsewhere that we need not be too concerned about bad patents issuing, since most such patents will never be litigated. Lemley, Rational Ignorance,supra note _ , at _ . But our data has shown that patents based on continuation applications are more likely than other sorts of patents to be litigated, meaning that the costs of permitting bad patents to issued based on continuation applications is significantly higher than average.

12735 U.S.C. $\S \S 134,141,145$.

128 This is a problem only if patent protection isn’t too strong already. If patents are too strong now, weakening some of them might be good for society on balance. We express no opinion on this general question.

It is worth noting that the most valuable patents are more likely than average to use continuation applications. Continuations represent $23 \%$ of all issued patents and $52 \%$ of all litigated patents. To conclude from this that continuations make patents valuable is probably to confuse cause and effect, however. Allison et al. find that patent applicants know in advance which patents are valuable, and use tools like the continuation application to maximize the scope of those valuable patents. Allison et al., Valuable Patents, supra note_, at _ . The technologies that underlie those patents would still be valuable if the continuation right didn't exist. 
has been limited in the last seven years by the rebirth of the written description requirement. ${ }^{129}$ With the exception of biotechnology, all the written description cases have involved changes made to patent claims during prosecution, and indeed one judge has argued that that is the only proper role for such claims. ${ }^{130}$ Abolishing continuation applications would all but eliminate the need for this much-criticized doctrine. ${ }^{131}$ It would therefore benefit patentees by removing a substantial threat to the validity of patents, a threat that has been used on occasion not just against amended claims but also against original claims. ${ }^{132}$

Second, the doctrine of prosecution history estoppel significantly limits the scope of patents under the doctrine of equivalents. Prosecution history estoppel arises when a patentee amends its claims during prosecution to narrow them for a reason related to patentability. ${ }^{133}$ When this happens, with two narrow exceptions the patentee gives up any claim under the doctrine of equivalents with respect to the amended claim element. ${ }^{134}$ The courts have applied the doctrine of prosecution history estoppel broadly, finding virtually any limiting amendment to be made for a reason related to patentability ${ }^{135}$ and refusing to accept post hoc arguments or

129 See, e.g., The Gentry Gallery Corp. v. The Berkline Corp., 134 F.3d 1473 (Fed. Cir. 1998); Hyatt v. Boone, 146 F.3d 1348 (Fed. Cir. 1998); Amgen, Inc. v. Hoechst Marion Roussel Inc., 314 F.3d 1313 (Fed. Cir. 2003); Cooper Cameron Corp. v. Kvaerner Oilfield Prods., 291 F.3d 1317 (Fed. Cir. 2002).

130 See Moba, B.V. v. Diamond Automation, Inc., 325 F.3d 1306, 1324-25 (Fed. Cir. 2003) (Rader, J., concurring).

131 See supra notes ____ and accompanying text.

132 See supra notes ____ and accompanying text.

133 Warner Jenkinson Co. v. Hilton Davis Chem. Co., 520 U.S. 17, 33 (1997).

134 Festo Corp. v. Shoketsu Kinzoku Kogyo Kabushiki Co., 535 U.S. 722 (2002). The two exceptions are where the effect of a claim change would not be foreseeable to a reasonable patent drafter, and where the intent of the claim change was tangential to the purpose for which it is now being asserted. Id. at 740-41.

135 Warner-Jenkinson created a presumption that any claim amendment that was not explained was necessary in order to issue the patent, and therefore would create an estoppel. Warner-Jenkinson, 520 U.S. at 33-34. Festo made it clear that estoppel applied not just to amendments made to avoid the prior art, but to amendments made for any reason at all related to the patentability of the invention. Festo, 535 U.S. at 736. 
boilerplate trying to explain away an amendment. ${ }^{136}$ The more likely a patent claim is to be amended during prosecution, therefore, the less likely it is to be entitled to protection under the doctrine of equivalents. And the more times an applicant goes back and forth with an examiner, the more likely they are to amend their claims. ${ }^{137}$ As a recent study by Doug Lichtman shows, there is good reason to believe that some examiners simply require claim amendments as a matter of course, not because of any particular defect in the application at hand. ${ }^{138}$ Abolishing continuations may therefore have the surprising effect of strengthening, not weakening, the scope of many patents by preserving the patentees' ability to argue for infringement under the doctrine of equivalents.

The most serious problem patent prosecutors would face if continuations were abolished comes from the Federal Circuit's 2002 en banc decision in Johnson \& Johnston v. R.E. Service Co. ${ }^{139}$ In that case, the Federal Circuit held that a patentee who disclosed an invention in the patent but failed to claim that invention could not obtain protection for it under the doctrine of equivalents. ${ }^{140}$ The court reasoned that the patentee was clearly aware of the invention, having described it in the patent specification, and should be required to claim the invention if she

136 See, e.g., Pioneer Magnetics, Inc. v. Micro Linear Corp., 330 F.3d 1352, 1357 (Fed. Cir. 2003) (holding that a patentee cannot escape the presumption by relying on arguments or testimony made after the fact); Bai v. L\&L Wings, 160 F.3d 1350, 1355 (Fed. Cir. 1998) (holding that a patentee cannot escape the presumption by including boilerplate language in the amendment stating that it was not made for a reason related to patentability).

137 Amendments or arguments made during the prosecution of related applications bind all subsequent applications in the chain. See, e.g., Mycogen Plant Sciences, Inc. v. Monsanto Co., 252 F.3d 1306, 1311 (Fed. Cir. 2001) (statements made in a parent application must be construed the same way as statements made in continuations).

138 Douglas G. Lichtman, 71 U. CHI. L. REV. __ (forthcoming 2004). See also Iain Cockburn et al., Are All Patent Examiners Equal? The Impact of Examiners on Patent Characteristics and Litigation Outcomes in PATENTS IN THE Knowledge-BAsed ECONOMY (Nat'l Academies Press 2003) at 19 (finding significant variation in the quality and behavior of patent examiners).

139285 F.3d 1046 (Fed. Cir. 2002) (en banc).

140 Id. at $1054-55$. 
wanted it included within the scope of the patent. ${ }^{141}$ The court did, however, permit patentees to recapture such disclosed inventions by filing a reissue patent or a continuation application. ${ }^{142}$ Abolishing continuation applications would increase the importance of the patent drafter getting it right the first time (prior to issuance) or the second time (during the two year reissue period). ${ }^{143}$ Getting rid of continuation practice would eliminate a mechanism that currently provides third (and fourth and fifth. . . ) chances. Requiring patent applicants to claim what they disclose doesn't seem an unreasonable burden to impose. And it is certainly consistent with giving adequate notice to competitors of what is and isn't covered by a patent, a policy goal the court has repeatedly emphasized. ${ }^{144}$ But it does put a premium on getting claims drafting just right, and abolishing continuations means that patent prosecutors would have to get it right at the outset.

In short, there are not many good reasons for society to allow continuation applications. The most that can be said in their defense is that patent prosecutors will have a somewhat harder job if continuations are abolished. But that job will be far from impossible, and patent owners may even benefit from abolition in the long run, since the claims they obtain will be more likely to be held valid and they will have a greater chance to employ the doctrine of equivalents.

\section{B. Scope of the Abolition}

\footnotetext{
141 Id. at 1055.
}

142 Id.

143 The patent law permits an applicant who failed to claim part of her invention to seek a broader patent within two years by filing a reissue application. 35 U.S.C. $\S 251$. In addition, patentees can seek to narrow their claims through the reissue process at any time. Id.

144 On the importance of notice to the public, see Warner-Jenkinson, 520 U.S. at 33; Johnson \& Johnston, 285 F.3d at 1052; Sage Prods. v. Devon Indus., 126 F.3d 1420 (Fed. Cir. 1997); Matthew J. Conigliaro et al., Foreseeability in Patent Law, 16 BeRKeley TECH. L.J. 1045, 1057 (2001) (discussing the importance of the notice function). 
Continuation applications are not a unitary phenomenon. We have focused our attention so far on what were traditionally called “continuation applications,” and have more recently been termed Continuing Prosecution Applications (CPAs) and finally Requests for Continuing Examination (RCEs). ${ }^{145}$ Two other types of continuation applications are common in patent prosecution, however. First, an applicant can file a "continuation-in-part" (CIP) application if she wishes to add new information to an existing application. ${ }^{146}$ CIP applications are entitled to claim priority back to the original application, but only for patent claims that arise out of the existing material, not claims based on the material added in the CIP. ${ }^{147}$ Second, the PTO will sometimes impose what is called a "restriction" requirement on an applicant who has identified two or more distinct inventions in a single application. Applicants can file a "divisional" application in response to a restriction requirement, separating their original application into two or more applications, each with claims directed to a different invention. ${ }^{148}$

If we abolish continuations, what should happen to CIPs and divisionals? Our answer is different for each. CIPs suffer from the same problems as continuations. They are under the control of the applicant, who can file an unlimited number of CIPs. They are subject to abuse by applicants who seek to delay issuance or publication of a patent, to obtain multiple patents, or to change claims during prosecution. Indeed, the potential for abuse of a CIP is even greater than with ordinary continuations, because CIPs allow the applicant to add new material to the application during the prosecution process while retaining an argument than any particular claim

145 The PTO created the term CPE in 1997. 62 Fed. Reg. 53132. It abolished the term CPE in favor of RCE in 2003. 37 C.F.R. § 1.53(d); see also 66 Fed. Reg. 35763.

14637 C.F.R. $\S 1.116$.

147 Merges ET AL., supra note _, at 116.

14835 U.S.C. $\S 121$. 
can be traced to the original material and therefore ought to be entitled to the original filing date. Applicants who wish to extend the duration of their patent can add "new matter"149 to their application, taking a chance that the new material has not been disclosed elsewhere. If the material is in fact new, or if the PTO decides the new matter is necessary to provide adequate disclosure for the claims, they can decide not to claim priority to the original application and start their 20-year clock running from the date of the CIP. If the new matter has in fact been disclosed in a prior art reference, they can argue that the original application adequately disclosed the invention, and claim priority to that application. ${ }^{150}$

By contrast, it is not clear that patent applicants have much legitimate need for CIPs any longer. If the new matter disclosed in the CIP is patentably distinct from that in the original application, the applicant doesn't need to file a CIP at all: she can simply file a new patent application. If the "new" matter is in fact the same invention as disclosed in the original application, the CIP effectively acts as a regular continuation application of the type we have already discussed. The traditional justification for the CIP has come in the middle cases, where the original disclosure was not strong enough to justify the current claims, but close enough that it would invalidate those claims if considered as prior art. This most commonly occurs when the applicant claims an invention that was not disclosed in the original application, but would be obvious in view of that application. But Congress changed the law in 1984 to permit most such

\footnotetext{
14935 U.S.C. $\$ 132$ prevents the addition of new matter during prosecution of an existing application; thus, it must be added in a CIP.

150 While the shift to a 20-year patent term foreclosed most opportunities for patentees to extend the length of their protection, CIP practice is a loophole. The Manual of Patent Examining Procedure does not require CIP applicants to decide immediately whether to claim priority to an original application. Rather, they can wait and see if they need priority, permitting them to engage in the game-playing described in text. U.S. PTO, Man. Pat. Exam. Proc. ๆ 201.08.
} 
applications to be patentable if filed separately, without the need for a CIP. ${ }^{151}$ After this statutory change, there is little reason why an applicant should need to file a CIP.

Divisional applications, by contrast, serve a useful purpose. They prevent an applicant from filing an omnibus application that overwhelms the patent office, either by including too many different claims and separate inventions to examine thoroughly ${ }^{152}$ or by including inventions in disparate areas of technology that would ordinarily go to different examiners with appropriate specializations. ${ }^{153}$ Divisionals are also less likely to be abused than continuations and CIPs. They are a response to a restriction requirement imposed by an examiner, so the PTO and not the applicant determines when they can be used. ${ }^{154}$ They tend only to be used once in any given prosecution, near the outset of prosecution, meaning that while a divisional may delay issuance somewhat it cannot delay prosecution indefinitely. Nor can divisionals be used to

151 The only reason the applicant could not file such a claim separately is if the original application constituted prior art to the new application. If the same inventor filed both applications, it would not constitute prior art except under 35 U.S.C. § 102(b), and then only if the original application was patented or published more than a year before the new application was even filed. This is both unlikely and avoidable.

If the new matter was filed by a slightly different group of inventors (say, Alice, Beth and Carol as opposed to just Alice and Beth on the original application), patent law used to bar such applications under section 102(e). But 35 U.S.C. §103(c) provides that as long as the group of inventors are the same or the assignee is the same (same employer), a prior application by one subset will not constitute prior art barring a later patent by a different subset. Section 103(c) eliminates the use of $\S \S 102(\mathrm{e})$, (f), or (g) prior art for obviousness determinations when there is common inventorship or assignment. This statute closed the loophole that justified filing CIPs.

152 For a proposal to introduce complexity weighting at the PTO, so that more complex applications get more attention, see Allison et al., Valuable Patents, supra note _, at _.

153 They also permit the PTO to collect more fees, perhaps one reason why anecdotal evidence suggests that the PTO has been issuing more restriction requirements.

154 There is some evidence suggesting that sophisticated applicants, particularly in the biotechnology field, may be intentionally filing multiple inventions in a single application in order to provoke a restriction requirement and therefore delay the prosecution of their claim. See Graham \& Mowery, supra note _ , at _ (noting that both the most valuable and the least valuable patents file divisional applications, suggesting that divisionals are sometimes used as a strategic tool and are sometimes a result of the applicant's ignorance of the rules). Even if this is happening, divisional applications are much less useful as a tool for delay and other forms of abuse than are continuations and CIPs. 
obtain multiple patents on the same invention, since claims written for each divisional application must stay on the proper side of the line drawn by the PTO. ${ }^{155}$

The abolition of continuations and CIPs would not end all abuse of the prosecution process. Some patent applicants may craft their applications in a way that provokes a restriction requirement, permitting them to divide their application after the first office action and add perhaps 14 months to total prosecution times. ${ }^{156}$ Other applicants might seek to provoke interferences with other pending applications in the hope of delaying prosecution. ${ }^{157}$ Still other applicants will choose to appeal if they can no longer file continuation applications. Appeals and interferences take a long time, ${ }^{158}$ and may therefore be an attractive way to delay patent prosecution. This is particularly true since the patent statute extends the patent term to compensate for delays caused by appeals and interference proceedings. ${ }^{159}$ But using appeals and interferences as delay tactics comes at a substantial cost. Appeals and interferences are both at least quasi-adversarial proceedings: there is someone arguing the other side. Unlike continuation practice, where the applicant gets an unlimited number of bites at the apple, if the applicant loses

15535 U.S.C. $\S 121$ provides that if the PTO requires an applicant to divide an application, it cannot cite one application against the other as prior art. See Applied Materials, Inc. v. Advanced Semiconductor Materials America, 98 F.3d 1563 (Fed. Cir. 1996). The courts have limited this rule with the principle of "consonance," however: a patentee who crosses the line by claiming the same invention in two different divisional applications may have those applications cited against each other as prior art. Texas Instruments, Inc. v. U.S. Int'l Trade Comm’n, 988 F.2d 1165 (Fed. Cir. 1993).

156 Graham and Mowery offer anecdotal evidence that this does occur, particularly in the pharmaceutical and biotechnology industries. See Graham \& Mowery, supra note _, at _.

15735 U.S.C. § 135 provides for administrative trials when more than one party claims the same invention. An applicant can "provoke" an interference by copying the claims from a pending or issued patent into her own application. For a discussion of interference litigation, see Lemley \& Chien, supra note _, at_.

158 Interferences spend an average of 30.5 months before the PTO, and certain infamous interferences have continued for decades. See Am. Intell. Prop. L. Ass'n, Committee Report: Patent-Relations With the U.S. PTO, http://www.aipla.org (data reported by PTO Board of Patent Appeals and Interferences Chief Judge Stoner). [add Wegner's data on time for interferences?]

15935 U.S.C. § 154(b)(1)(C). 
they get nothing. ${ }^{160}$ And even if they ultimately prevail, neither appeals nor interferences permit applicants to obtain multiple patents or to obtain a narrow patent while awaiting resolution of an argument for a broader one.

\section{Alternatives to Abolition}

Abolishing patent continuations would require legislative action. ${ }^{161}$ Recent experience with patent system reform suggests that this legislative change might prove controversial. ${ }^{162}$ Individual inventors, who have proven surprisingly powerful in influencing Congress, ${ }^{163}$ are

160 Applicants can appeal an adverse decision by the BPAI to the Federal Circuit, 35 U.S.C. $\S 141$, or in the case of interferences to a district court and then to the Federal Circuit. 35 U.S.C. § 146. But the PTO Solicitor's office will actively defend the Board's decision on appeal, and in the case of an interference another interested party will also oppose the applicant's claim.

161 Continuation applications are provided for in 35 U.S.C. §120, and CIPs in 35 U.S.C. §132(b).

162 Even modest efforts to reform the patent system in the late 1990s to harmonize it with the rest of the world proved politically divisive. Independent inventors and conservative politicians opposed harmonization. See, e.g., Dana Rohrabacher \& Paul Crilly, The Case for a Strong Patent System, 8 HARV. J.L. \& TECH. 263 (1995); 140 CONG. REC. H11,450, 11,456 (daily ed. Nov. 29, 1994) (statements of Reps. Bentley \& Rohrabacher opposing harmonization because they claimed it was demanded by Japan and permitted big Japanese and multinational corporations to steal the patent rights of American inventors); James J. Barta Jr., Death of a Superior Intellectual Property Law System, 17 ST. L. U. PuB. L. REV. 383 (1998). For a discussion of the political debate, see John F. Duffy et al., Early Patent Publication: A Boon or Bane? A Discussion on the Legal and Economic Effects of Purchasing Patent Applications After Eighteen Months of Filing, 16 CARDOZO ARTS \& ENT. L.J. 601, 604 (1998); Stephanie Gore, “Eureka! But I Filed Too Late . . .”: The Harm/Benefit Dichotomy of a First-to-File Patent System, 1993 U. Chi. L. SCH. Roundtable 293; Mark A. Lemley, An Empirical Study of the Twenty-Year Patent Term, 22 AIPLA Q.J. 369 (1994). On the power of the small inventor as an icon, see Mark D. Janis, Patent Abolitionism, 17 BERKELEY TECH. L.J. 899, 910 (2002).

The effect of this political firestorm was that patent reform was delayed for several years, and when it did come it was so watered down as to be completely ineffective. For example, the U.S. patent law now includes a 20year term, 18-month publication, a limited prior user right, and an inter partes opposition procedure. 35 U.S.C. §§ 154(a)(2), 122(b), 271, 311-318 (2000). In each case, however, Congress so watered down the new provisions that they bear little resemblance to their foreign counterparts. Thus, the 20-year term is riddled with extensions, 35 U.S.C. § 154(b) (2000); 18-month publication is required only for inventors who also file abroad, 35 U.S.C. § 122(b)(1)(B) (2000); the prior user right applies only to business method patents, and even then only in extreme cases, 35 U.S.C. § 273(b)(3); and the opposition procedure is so anemic that virtually no one seems willing to use it. 35 U.S.C. §§ 311-318 (2000); United States Patent \& Trademark Office, Inter Partes Reexamination Filing Data (December 31, 2002) (only 7 inter partes reexamination requests were filed between 1999 and 2002, compared with 6,501 normal reexamination requests). For a description of those shortcomings, see 35 U.S.C. § 315(c) (2000); Mark D. Janis, Inter Partes Patent Reexamination, 10 FordHAM InTELL. Prop. MEDIA \& ENT. L.J. 481 (2000).

163 See Janis, Abolitionism, supra note _, at 918-19 (changes in the AIPA "bear the unmistakable influence of lobbying on behalf of independent inventors.”). 
more likely than other inventors to abuse the continuation process, ${ }^{164}$ and they may object to outright abolition. Further, the patent bar organizations are predominantly composed of patent prosecutors, who stand to lose some of their business if patent prosecution becomes less protracted. As a result, they would likely such a proposal as well. The primary beneficiaries of abolition - companies who make products that might be the subject of patent holdup, and the customers who pay a lower price for those products - have a diffuse interest and may be difficult to organize around a reform measure.

In addition, the number of patentees who abuse continuation practice seems to be small ${ }^{165}$ and may not justify such a sweeping change to long standing patent practice. We propose here a number of partial steps Congress or the courts might take to address the abusers. In this section, we address three possible ways to address the abuse of continuation practice in a world in which the continuation application remains a reality.

\section{Limit the Number of Continuations}

Even if policymakers conclude there are good reasons to permit patentees to file continuation applications in an effort to argue for the claims they want, those reasons don't justify an unlimited number of continuation applications. A compromise proposal might, therefore, limit each applicant to no more than one continuation application or CIP. In each application, the inventor has at least two, and generally more, attempts to persuade the examiner

\footnotetext{
164 Individuals obtained $26 \%$ of the continuation patents with delays of twenty years or more. Although individuals are actually less likely to file continuations generally (individuals obtain $18 \%$ of all issued patents and $15 \%$ of all continuation patents), a few highly visible individual inventors are more likely to abuse the practice by filing multiple continuations stretching prosecution out many years. Cf. Allison \& Lemley, Who's Patenting What?, supra note _, at 2140 (finding no statistically significant relationship between entity size and the number of continuation applications filed).

${ }^{165}$ See Table 1 in the Appendix which shows that less than $1 \%$ of all patents take more than nine years to issue.
} 
of the justice of the applicant's position. ${ }^{166}$ Allowing even one continuation application will give the applicant five or six bites at the apple. Surely that is enough. ${ }^{167}$

Eliminating multiple continuation applications would also deal with the worst abusers of the system. In the past, a small number of applicants have filed a large number of continuation applications. For example, of the thirty-three patents with the longest prosecution delays (thirtytwo to nearly fifty-four years), twenty-three of them belong to Jerome Lemelson and five belong to George Sawyer. Of the remaining five, two took so long because of secrecy orders restricting their issuance. As these numbers demonstrate, a small number of inventors are among the worst abusers of continuation practice.

Multiple continuations can be harmful in another way. One U.S. patent claims priority to 98 different related applications. ${ }^{168}$ This patent claims to be a continuation-in-part of seventeen different applications each with their own priority chains. For these types of patents, there is no way the public can have any idea which claims are entitled to which priority date or when the various claims will expire. Although it is unusual to have this many priority claims -- the mean for all issued patents is a claim of priority to 0.36 applications -- it demonstrates the confusion that can be caused by continuation practice.

\section{Preventing Broadening of Claims During Continuation Applications}

\footnotetext{
166 An applicant presents an initial set of claims, faces an initial rejection, gets at least one chance to amend the claims or argue for the original claims before facing a final rejection, and then usually gets an opportunity for an offthe-record personal or telephonic interview with the examiner. A striking number of claims that are "finally rejected" before the interview end up being allowed with little or no explanation after the interview. For a discussion of this process, see John R. Thomas, On Preparatory Texts and Proprietary Technologies, 47 UCLA L. REV. 183 (1999).

167 Of course, the patentee could still use the reissue process within two years of the patent issuance to argue once again for broader claims; in effect giving the applicant yet another chance. 35 U.S.C. §251.

168 U.S. Patent No. 5,714,566. Similarly, U.S. Patent 5,640,805 claims priority to 82 different applications through ten different application chains.
} 
One of the most egregious abuses of continuation applications described above is the use of the process to change patent claims to track inventions first made not by the applicant but by a competitor. ${ }^{169}$ Central to this use of the continuation practice is the ability of the applicant not only to change claims during prosecution, but to broaden those claims to cover inventions that may or may not be supported in the initial disclosure, but were not within the scope of the claims as initially filed. Permitting applicants to broaden claims allows them to correct errors, and it may be important to do so in an era in which failing to claim the full range of your invention will also disable an applicant from relying on the doctrine of equivalents. ${ }^{170}$ But it also invites abuse of the system.

One partial solution to this problem would be to permit applicants to file continuation applications, but not to permit them to broaden the scope of their claims during the prosecution of those applications. ${ }^{171}$ Patentees would have to correct any unintended narrowness in their claims during the prosecution of the initial application, or alternatively in a reissue proceeding within two years after the patent issued. ${ }^{172}$ They could file continuation applications in order to persuade the PTO that they were entitled to broad claims, or to narrow their claims sufficiently to make them patentable. But they could not capture new ground with claims offered for the first time in a continuation application. This approach would deal with one specific abuse associated with continuation applications. It would do nothing about delay, secrecy, or multiple patenting,

169 See supra notes ____ and accompanying text.

170 Johnson \& Johnston Assoc. v. R.E. Serv. Co., 285 F.3d 1046 (Fed. Cir. 2002) (en banc). See supra notes _-_ and accompanying text (discussing this rule).

171 If abuse of the appeal and interference processes were determined to be a significant problem, this proposal could also be applied to prosecution after a successful appeal or interference proceeding.

172 Broadening reissues, unlike continuation applications, give "intervening rights" to companies who started using an invention covered by the newly broadened claims before those claims were issued. See 35 U.S.C. §252. The reissue process therefore protects against unscrupulous applicants who change their claims to track their competitors' new inventions. 
however. It would also impose many of the same burdens on patent prosecutors as abolishing continuations.

\section{Publishing Applications}

Another alternative would be to institute more meaningful publication requirements. A first step, since the exceptions at present threaten to swallow the rule, is to eliminate the "optional" nature of publication. If all applications were publishing regardless of whether the applicant intends to file abroad, it would minimize the surprise associated with submarine patents. Moreover, with the creation of provisional damages for those who infringe published applications that ultimately issue, ${ }^{173}$ there is little reason to be concerned with the threat to inventors of having their published technology usurped during the pendency of the patent prosecution. ${ }^{174}$ Provisional rights give patentees a reasonable royalty for infringement that occurs after publication but before patent issuance provided that the infringer has actual notice of the published application and that the infringer would have infringed under both the published version of the claims and the issued version of the claims. ${ }^{175}$ Requiring infringement to occur under both versions of claims is beneficial because it creates an incentive to have the broadest claims included in the application from the beginning. If broader claims are added after publication, and the infringer would not have infringed the published claims, the patentee has no cause of action for the infringement until after the patent issues. Closing loopholes in the

\footnotetext{
17335 U.S.C. $\$ 154(d)$.
}

174 The fact that a patent, when it issues, will be enforced by injunctive relief, see 35 U.S.C. §283, also makes such use of inventions disclosed in pending applications unlikely. A company that starts producing infringing products based on a published patent application knows that it will soon have to shut down production once the patent issues. Further, anyone who learns of a technology from a published patent application will likely be a willful infringer subject to treble damages.

17535 U.S.C. §154(d). 
publication requirement would help minimize the uncertainty associated with submarine patents, but it would do nothing about delay, multiple patenting, or filing subsequent claims to cover a competitor's technology.

\section{Intervening Rights}

Another alternative that would eliminate many of the perils of submarine patents would be the creation of intervening rights for competitors who began making, using, or selling the patented invention prior to the broadening continuation. Intervening rights already protect competitors from having the patentee broaden issued patent claims to cover their products through a reissue patent. ${ }^{176}$ Intervening rights for broadening continuations could work the same way. ${ }^{177}$ Continuation-based intervening rights could limit liability to those circumstances when the infringer would have infringed both the claims in the original application and the ultimately issued continuation patent claims. Although claim construction and infringement determinations for a single claim is hard enough, and this test would double the court's workload by requiring it to determine infringement of both claims, there is an established body of law on both whether a reissue is broadening ${ }^{178}$ and the scope of intervening rights. ${ }^{179}$ The "substantial identity" test

\footnotetext{
${ }^{176}$ For a discussion of equitable and absolute intervening rights in the context of broadening reissue see Timothy R. Holbrook, Liability For the "Threat of a Sale": Assessing Patenting Infringement for the On-Sale Patentability Bar and Other Forms of Infringement, 43 SANTA Clara L. Rev. 751, 769-770 (2003). See also J. Christopher Carraway, The Uncertain Future of Enforcing Patents that Have Been Broadened Through Reissue, 8 FED. CIR. B.J. 63 (1998).

177 The Federal Circuit declined to create such a doctrine judicially in Ricoh Co. v. Nashua Corp., 185 F.3d 884 (Fed. Cir. 1999) (holding that intervening rights are reserved for broadening reissue patent and not available for broadening continuations) (unpublished decision). Ricoh is an unpublished decision of the Federal Circuit and therefore is not binding precedent. And in any event there is nothing that would prevent Congress from creating such a right expressly.
}

178 See, e.g., Hockerson-Halberstadt, Inc. v. Converse, Inc., 183 F.3d 1369 (Fed. Cir. 1999); Vectra Fitness v. TNWK Corp., 162 F.3d 1379 (Fed. Cir. 1998); Mentor Corp. v. Coloplast, Inc., 998 F.2d 992 (Fed. Cir. 1993). 
used for both reissue-based intervening rights and the new provisional rights accorded to published applications could be applied to continuation-based broadening of claims as well. ${ }^{180}$

Another model for reform besides intervening rights in reissues is the prior user right. Many European countries grant a limited right to independent developers to continue using technology they developed before the patent issued. ${ }^{181}$ In the United States, recent legislation established a prior user right defense to patent infringement for business method patents. ${ }^{182}$ Under that provision, prior user rights exist as a defense to infringement if the prior user reduced the invention to practice more than one year before the patent claims were filed and commercially used the invention before the claims were filed. ${ }^{183}$

While intervening rights would minimize the use of continuations to obtain claims to read on a competitor's product where the patentee had not contemplated the embodiment prior to seeing the competitor's device, ${ }^{184}$ a particularly offensive practice, it would not solve other

179 See, e.g., BIC Leisure Products v. Windsurfing Int'l, 1 F.3d 1214 (Fed. Cir. 1993); Shockley v. Arcan, Inc., 248 F.3d 1349 (Fed. Cir. 2001).

180 See Philippe Signore, The New Provisional Rights Provision, 82 J. PAT. \& Trademark OfF. Soc'Y 742, 752-54 (2000).

181 Robert Merges has called for a system of prior user rights on the European model, and a number of commentators have suggested the creation of a limited defense of some sort for independent inventors. See, e.g., Michelle Armond, Comment, Introducing the Defense of Independent Invention to Motions for Preliminary Injunctions in Patent Infringement Lawsuits, 91 CAL. L. REV. 117 (2003); Stephen M. Maurer \& Suzanne Scotchmer, The Independent Invention Defense in Intellectual Property, 69 Economica 535 (2002); John S. Liebovitz, Note, Inventing a Nonexclusive Patent System, 111 YALE L.J. 2251 (2002).

18235 U.S.C. §273(b).

183 Id.

${ }^{184}$ We say minimize rather than eliminate because we can envision circumstances where applicants could game the system to avoid intervening rights. If the applicant filed a few extremely broad claims initially, even if they knew these claims would be rejected, then prosecuted more narrow claims, then later filed a continuation with claims to read on a competitor's device that were broader than those obtained, but narrower then those originally applied for. In this circumstance, the originally filed claims would likely have been broad enough to cover the competitor and therefore, no intervening rights would likely arise. 
continuation-based problems. For example, intervening rights would not eliminate attempts to wear down the examiner by fighting over-and-over again for broad claims.

\section{Limiting the Time an Application Can Spend in Prosecution}

An alternative to abolishing or restricting the use of continuation applications is to permit the use of those applications, but to set an independent limit on the amount of time an application can spend in prosecution. Unlike our other proposals, this one can be implemented retroactively and without legislative reform. Indeed, the Federal Circuit has done something very similar in the last two years by creating a new equitable defense of continuing prosecution laches. ${ }^{185}$ If continuation applications persist, this new doctrine serves an important function in preventing abuses of the system. The major problems with the laches doctrine are: (1) the parameters of the doctrine and its application are not, at present, well defined; ${ }^{186}$ and (2) courts lack clear standards and hard evidence upon which to base a decision on reasonableness. In order for it to be effective, the doctrine needs some certainty. Both applicants and competitors should have a decent idea when the doctrine will apply. While the first problem will likely correct itself in time, the second may not. As the Federal Circuit has an opportunity to evaluate laches cases, and precedent on the issue evolves, the defense will become better defined. One of the major

185 See, e.g., Symbol Techs. v. Lemelson, 277 F.3d 1361 (Fed. Cir. 2002); In re Bogese, 303 F.3d 1362 (Fed. Cir. 2002). A district court opinion has confirmed that the doctrine of prosecution laches applies even to applications subject to the twenty-year term, see Digital Control, Inc. v. McLaughlin Mfg. Co., 225 F. Supp. 2d 1224 (W.D. Wash. 2002), though the court in that case rejected the prosecution laches claim because the delay was not unreasonable. Digital Control, Inc. v. McLaughlin Mfg. Co., 248 F. Supp. 2d 1015 (W.D. Wash. 2003).

186 Reiffin v. Microsoft Corp., --- F.Supp.2d ----, 2003 WL 21544105, at *16 (N.D. Cal., Mar 31, 2003) (NO. C 98266) ("the Symbol court did little to clarify the elements of the defense, its scope or the burden of proof required to demonstrate it”). See also Michael T. Hawkins, Prosecution Laches in the Wake of Symbol Technologies: What is "Unreasonable and Unexplained Delay?, 87 MiNN. L. REV. 1621, 1648 (2003) ("Although the ultimate conclusion of the Symbol Technologies court was well reasoned, the court provided little guidance on how to apply the doctrine.”); Jennifer C. Kuhn , Symbol Technologies: The (Re)Birth of Prosecution Laches, 12 FED. CIR. B.J. 611 (2003). 
contributions of our empirical research is to help facilitate the laches analysis by providing evidence on the distribution of prosecution delays. This evidence will provide courts with a baseline for their reasonableness analysis. We cannot help but offer some guidance on the applicability of the defense as well.

To date, no district court has found that prosecution laches ought to apply to any of the patents in which the defense was raised. ${ }^{187}$ The Federal Circuit held that laches ought to apply to bar the enforceability of a patent when there was "an unreasonable and unexplained delay" in prosecution. $^{188}$ What the laches cases decided thus far have lacked was evidence regarding normal, average, mean or "reasonable" prosecution times. If the judges do not have a baseline for assessing how long is too long, then it is difficult for them to find a particular delay unreasonable, especially where both sides present patent experts who give opposing opinions on the issue. The empirical results presented in this paper provide a baseline for assessing the reasonableness of prosecution length.

187 This is true despite some pretty lengthy prosecutions. See, e.g., Reiffin v. Microsoft Corp., --- F. Supp. 2d ----, 2003 WL 21544105 (N.D. Cal. Mar 31, 2003) (NO. C 98-266) (denying summary judgment of laches for delays in prosecution of eleven years from the claimed priority date to when the claims at issue were added during prosecution); Stambler v. RSA Security, Inc., 243 F. Supp. 2d 74, 74-75 (D. Del. 2003) (finding no reasonable delay as a matter of law where the delay between the original claim to priority and the issuance of the final patent was approximately seven years); Cummins-Allison Corp. v. Glory Ltd., 2003 WL 355470 (N.D. Ill. 2003) (denying preliminary injunction because defendant did not prove a likelihood of success of prosecution laches where delay was more than ten years from the earliest claim of priority to the filing of the claims at issue); Digital Control Inc. v. McLaughlin Mfg Co., 225 F. Supp. 2d 1224, 1228 (W.D. Wash. 2002) (granting patentee summary judgment of no laches even where delay from earliest priority to issue was 10 years $21 / 2$ months); Intuitive Surgical, Inc. v. Computer Motion, Inc., 2002 WL 31833867 (D. Del. 2002) (holding no laches where delay from earliest claim of priority to issuance was nearly nine years); but cf. Chiron Corp. v. Genentech, Inc, 268 F. Supp. 2d 1139 (E.D. Cal. 2002) (denying summary judgment to patentee on laches issue because delay of more than fifteen years from earliest filing date to issuance was unexplained). The only case in which prosecution laches was found, In re Bogese II, the PTO held claims unenforceable where the applicant filed eight continuations, each on nearly the last possible day, each after a final rejection, each with no claim changes or amendments. In re Bogese II, 303 F.3d 1362 (Fed. Cir. 2002). This delay in prosecution spanned nearly eight years, from April 6, 1987 to January 23, 1995. Id. at 1364. Prior these delays, Bogese had actually appealed rejections to the Board and then to the Federal Circuit, but the court did not consider this to be part of the unreasonable delay. Id. Bogese is a textbook case of trying to wear down the examiner.

188 Symbol, 277 F.3d at 1363. 
As Figure 3 shows, the median amount of time patents spend in prosecution from their earliest filing date to issuance is 2.04 years; the mean is 2.47. Figure 3 is a plot of the distribution of patents by the amount of time spent in prosecution. Figure 4 is an inverse cumulative plot of patent prosecution time. At any given year on the $\mathrm{x}$ axis it plots the percentage of patents still in prosecution. For example, six years after a filing date only 3.66\% of all patent applications are still pending. ${ }^{189}$

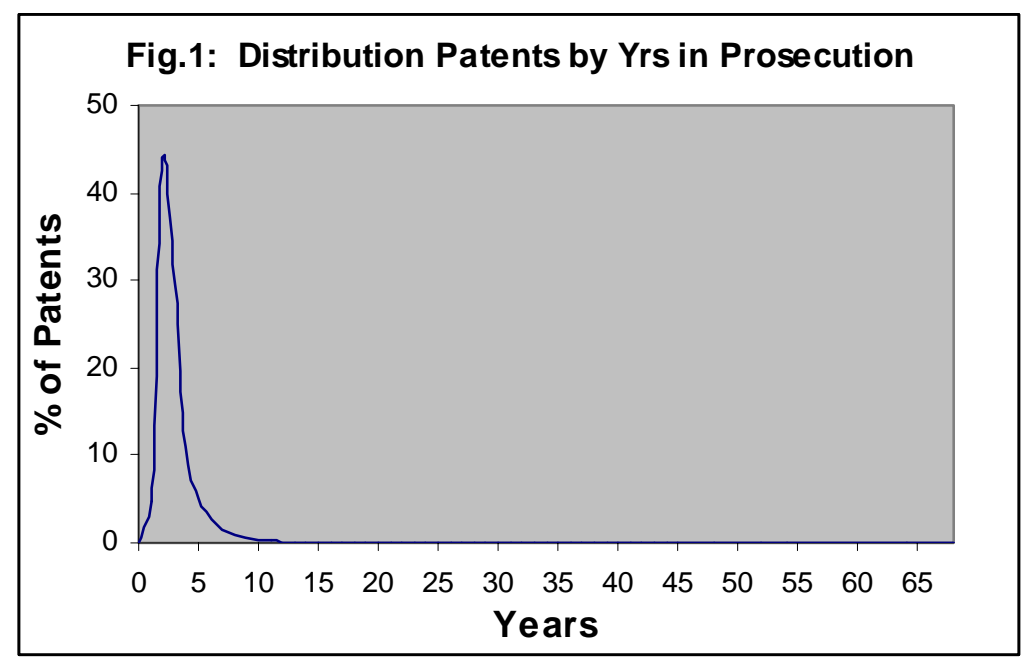

\footnotetext{
189 While 3.66 percent does not sound like a lot, in raw numbers it can actually be quite intimidating. As Table 1 indicates 81,389 patents took six years or longer from earliest filing date to issuance. Many of these patents, however, have already expired since they issued more than seventeen years ago, leaving 63,882 patents still potentially enforceable. Of these, 57,480 (nearly $90 \%$ ) are continuations. Undoubtedly some of these patents would have expired due to failure to pay maintenance fees making the raw number even smaller. While a six year presumption would potentially call into question 50,000 issued patents, it is important to keep in mind that while approximately 150,000 patents issue each year only about 3000 end up being litigated and $75 \%$ of the litigated cases settle. In short, the raw number of patents encompassed by the six year rule is not likely to be unreasonably large.
} 


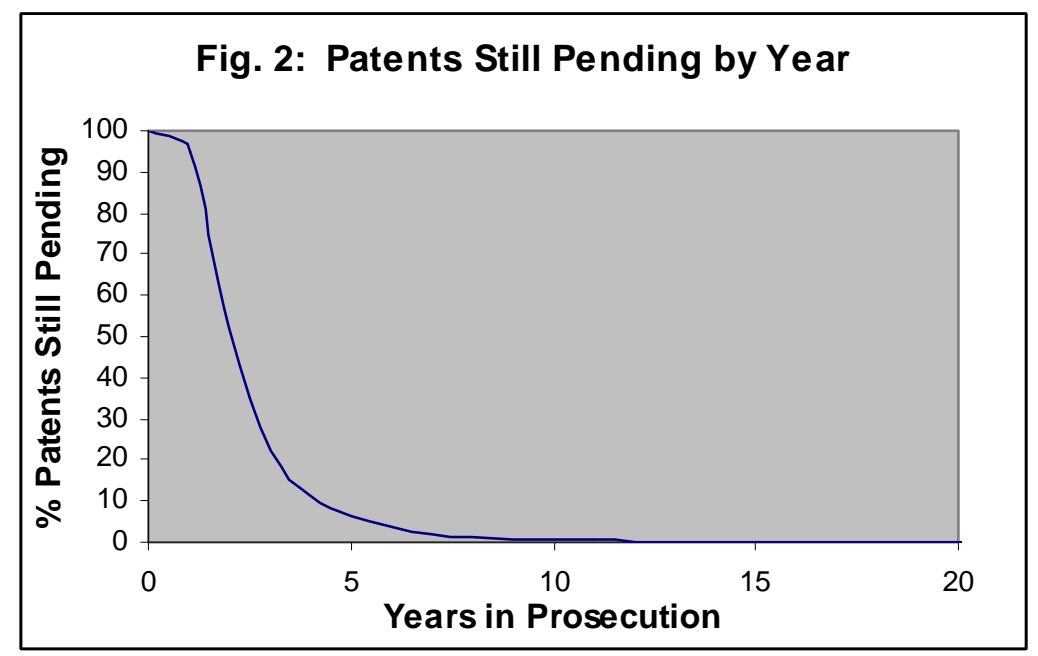

We suggest that any patent pending six years or longer ought to automatically be subject to scrutiny for laches - a presumption of laches. ${ }^{190}$ Six years is more than two standard deviations from the mean of 2.47 years. ${ }^{191}$ Although there is some variation by technology in the mean amount of time an application spends in prosecution, that variation is not substantial and would not be significant if a six year presumption were created. For example, measuring the time from the most recent filing date to issuance date of the patents issued in each technological class, ${ }^{192}$ the technology class with the shortest mean 1.53 years was class 150 Purses, Wallets and Protective Covers and the technology class with the longest application time of 3.18 years

190 This is not to say that patents which take less time to prosecute could not be guilty of laches. We have just selected six years as a benchmark period which ought to always trigger a laches inquiry. The Federal Circuit created a similar six-year presumption for litigation rather than prosecution laches in A.C. Aukerman Co. v. R.L. Chaides Constr. Co., 960 F.2d 1020 (Fed. Cir. 1992).

191 The mean time in prosecution of all patents granted from 1976-2000 is 2.4690 years. The standard deviation is 1.6295. Hence two standard deviations away from the mean is 5.7280. A six year presumption is thus more than to standard deviations away from the mean prosecution time.

192 If we measured time from earliest claim of priority to issuance the difference is more substantial. The class with the shortest mean was class 38 Textiles: Ironing or Smoothing, with a mean prosecution time of 1.68 years and the class with the longest prosecution time of 4.08 years was 530, Chemistry: Natural Resins or Derivatives; Peptides or Proteins; Lignins or Reactions Products Thereof. This variation is almost entirely attributed to the likelihood that members of each class filed continuations and multiple continuations. In class 38 , only $7 \%$ of all applications claim priority to earlier filed applications (small number of continuations). In class 530, 50\% of all patents were continuations. The complexity of the technology does of course have some impact as well. In class 38 , time from filing to issuance was 1.58 and in class 530 it was 2.52 years. 
was 380 Cryptography. The difference in prosecution time may be somewhat related to the complexity of the technology, but in the case of cryptography many of the patents that issued in this class were delayed because of secrecy orders related to national security issues. Having reviewed the data on each technology class, we conclude that while there is variation by class, the six year presumption is fair to all classes and absent other factors, ${ }^{193}$ difference in technology do not justify different presumptive laches periods.

The six year presumption of prosecution laches would be measured from the earliest continuation filing date to which the patentee claims priority to the issuance date. ${ }^{194}$ Six years is a logical time period to choose as it also mirrors the litigation laches period. If a patentee delays filing suit longer than six years from when she knew or should have know of a potential infringer, a presumption of laches applies. ${ }^{195}$ Of course, like litigation laches, the prosecution laches presumption ought to be rebuttable. If the patentee can demonstrate that the delay was not unreasonable but instead there was a legitimate reason why prosecution took so long, then it

193 Since the number of claims and prior art references cited did significantly affect prosecution, we believe that these factors could be considered by a court in determining whether the delay is unreasonable. A large number of claims and prior art reference may cause the examiner to spend more time on the application or may cause the examiner to put off examination due to the complexity. In either event, lengthy prosecution in this case would be due to PTO delay, not applicant delay. Of course, to be a reason for the delay, the large number of claims and prior art would have to be present in each of the applications in the chain. If an applicant files ten claims initially with several continuations and finally files a continuation with 100 claims ten years after the initial filing, the number of claims cannot be said to have caused the ten year delay.

${ }^{194}$ We recognize that there could be many ways to measure the relevant time period for laches inquiries. We propose the simplest - measure from earliest claim of priority to issuance. Of course we could alternatively measure from the filing date of the patent to which priority is claimed to the filing date of the claims being asserted in the issued patent. This would measure how long the patentee delayed in filing the relevant claims. Such a measure would entirely forgive patentees who file the same claims over and over to wear down the examiner which we think ought not to be encouraged. A measure from filing date to filing date would encourage patentees to file exceptionally broad claims initially then prosecute the narrower ones iteratively. That way they could have lengthy delays, but claim to be immune from laches because they had filed the broad claims initially. Measuring from filing to filing date would also open the door to disputes regarding the scope of the original claims. Patentees would undoubtedly argue that their original (rejected) claims did in fact cover the embodiments claimed in continuations. This would cause district courts to suffer through construction of not only the claims at issue, but rejected claims from earlier applications.

195 See, e.g., A.C. Aukerman Co. v. R.L. Chaides Constr. Co., 960 F.2d 1020, 1028 (Fed. Cir. 1992) (en banc) (explaining that six year laches presumption). 
ought to be able to overcome the presumption. We can think of several reasons that ought to rebut the presumption: (1) delay caused by an appeal to the Board, the district court, or the Federal Circuit; (2) delay caused by an interference; (3) delay caused by PTO error, or (4) delay caused by a secrecy order that prohibited the patent from issuing.

Patentees should not be able to defend against the presumption merely on the grounds that they did not break any laws by filing multiple continuations. That argument, if accepted, would defeat the doctrine of prosecution laches entirely. Prosecution laches is an equitable defense and therefore ought to apply even where a patentee did not violate the letter of the law, but when equity would dictate that the unreasonable delay render the patent unenforceable. Moreover, arguments that an applicant decided to prosecute her applications in series rather than in parallel, ${ }^{196}$ or filed a terminal disclaimer ${ }^{197}$ should not be sufficient to overcome the presumption. The harms from laches are twofold: (1) "unreasonably delaying the issuance of a patent and attendant publication of an invention for the purpose of maximizing its commercial value” and (2) unduly postponing the time when the public can have free use of the invention (extending the monopoly period). ${ }^{198}$ Filing a terminal disclaimer may obviate the second harm caused by unreasonable delay, the monopoly is not extended, but it does not address the first, and is therefore not an explanation sufficient to overcome laches.

\footnotetext{
196 Serial prosecution means that the applicant decided to prosecute the applications one at a time. Hence she would turn to the new application only after the old one was finished. In general we have no problem with this approach to prosecution, but we think that the applicant ought not to be entitled to the earlier filing date of the continuation application unless they are actually continuing the patent prosecution. A decision to prosecute in series is not meaningfully advancing prosecution on each application.

197 Patentees may argue that the filing of a terminal disclaimer eliminates the extension of the monopoly that may result from the delay. This generally matters only for application filed before the change to the twenty-year patent term.

198 Reiffen, 2003 WL 21544105, at *21 (citing Woodbridge v. United States, 263 U.S. 50, 58, 60 (1923)).
} 
Finally, unlike litigation laches, prosecution laches ought to be a one-part test: did the patentee delay prosecution for an unreasonable length of time. ${ }^{199}$ While litigation laches also requires proof that the delay operated to the prejudice or injury of the defendant, ${ }^{200}$ prosecution laches ought not to have such a requirement. ${ }^{201}$ Unlike litigation laches, which is designed to preserve the validity of a patent while preventing injustice to a particular defendant who relied on the patentee's acquiescence, prosecution laches is intended to render the patent unenforceable as a whole. Even if the Federal Circuit should find that proof of both unreasonable delay and material prejudice are required, when our presumption applies (the patent was prosecuted six years or longer), a prima facie case of laches is made, and both unreasonable delay and material prejudice ought to be inferred. $^{202}$

\section{Conclusion}

Continuation applications have led to abuse of the patent prosecution process. They serve very little useful purpose, and what benefits they confer may be outweighed by their potential for mischief. The world would probably be a better place if they were abolished. Recognizing, however, that the abuse of continuation practice is not as pervasive as some might

199 As an equitable doctrine, prosecution laches is for the court, not the jury, to decide and it seems as though it would most always be resolvable on summary judgment.

200 See A.C. Aukerman Co., 960 F.2d at 1032 (explaining the two-part test for litigation laches).

201 See Reiffen, 2003 WL 21544105, at *20 (suggesting that proof of unreasonable delay should be the only factor in the prosecution laches inquiry). "Prosecution laches is not a doctrine, like traditional laches, aimed to protect specific competitors. It rather serves the broader public interests in the timely issuance of patents.” Id. at *22.

202 If the Federal Circuit concludes that proof of material prejudice is required, then it seems that adoption of one's technology and use in commerce prior to the filing by the patentee of the broader claims ought to suffice to establish such prejudice. It seems that prejudice would be even clearer if the patentee obtained a related patent with narrower claims issued (such as a parent or grandparent), the infringer adopts and uses technology it believes designs around the claims, and the patentee then filed broader claims to read on the infringer's device. 
think, we propose a number of means by which Congress and the courts could strengthen existing rules designed to limit their abuse while preserving the practice. 


\section{Appendix}

\begin{tabular}{|c|c|c|c|c|c|}
\hline YEAR ${ }^{203}$ & \# of Patents & $\begin{array}{l}\text { Distribution } \\
(\%)^{204}\end{array}$ & Cumulative \# & $\begin{array}{l}\text { Cumulative } \\
(\%)^{205}\end{array}$ & $\begin{array}{l}\text { Inverse Cum. } \\
(\%)^{206}\end{array}$ \\
\hline 0 & 3 & 0.00 & 3 & 0.00 & 100.00 \\
\hline 1 & 109121 & 4.91 & 109124 & 4.91 & 95.09 \\
\hline 2 & 964672 & 43.37 & 1073796 & 48.27 & 51.73 \\
\hline 3 & 655933 & 29.49 & 1729729 & 77.76 & 22.24 \\
\hline 4 & 243734 & 10.96 & 1973463 & 88.72 & 11.28 \\
\hline 5 & 111266 & 5.00 & 2084729 & 93.72 & 6.28 \\
\hline 6 & 58271 & 2.62 & 2143000 & 96.34 & 3.66 \\
\hline 7 & 32145 & 1.45 & 2175145 & 97.79 & 2.21 \\
\hline 8 & 18574 & 0.84 & 2193719 & 98.62 & 1.38 \\
\hline 9 & 10746 & 0.48 & 2204465 & 99.10 & 0.90 \\
\hline 10 & 6620 & 0.30 & 2211085 & 99.40 & 0.60 \\
\hline 11 & 4168 & 0.19 & 2215253 & 99.59 & 0.41 \\
\hline 12 & 2753 & 0.12 & 2218006 & 99.71 & 0.29 \\
\hline 13 & 1822 & 0.08 & 2219828 & 99.79 & 0.21 \\
\hline 14 & 1201 & 0.05 & 2221029 & 99.85 & 0.15 \\
\hline 15 & 847 & 0.04 & 2221876 & 99.89 & 0.11 \\
\hline 16 & 577 & 0.03 & 2222453 & 99.91 & 0.09 \\
\hline 17 & 404 & 0.02 & 2222857 & 99.93 & 0.07 \\
\hline 18 & 323 & 0.01 & 2223180 & 99.95 & 0.05 \\
\hline 19 & 181 & 0.01 & 2223361 & 99.95 & 0.05 \\
\hline 20 & 177 & 0.01 & 2223538 & 99.96 & 0.04 \\
\hline 21 & 110 & 0.00 & 2223648 & 99.97 & 0.03 \\
\hline 22 & 114 & 0.01 & 2223762 & 99.97 & 0.03 \\
\hline 23 & 67 & 0.00 & 2223829 & 99.97 & 0.03 \\
\hline 24 & 96 & 0.00 & 2223925 & 99.98 & 0.02 \\
\hline 25 & 86 & 0.00 & 2224011 & 99.98 & 0.02 \\
\hline
\end{tabular}

\footnotetext{
${ }^{203}$ Year is measured as follows: 0 is zero years, 1 year includes everything greater than zero and less than one, 2 year includes one up to two years, three includes two up to three years, etc.

204 Distribution is the distribution of patents that took a particular number of years to issue. For example, 0 years measures all patents with a prosecution time of zero years; 1 year measures all patents with a prosecution time from 0 up to 1 year; 2 years measures all patents with a prosecution time of 1 year up to 2 years, etc.

${ }^{205}$ Cumulative measures all patents that took that long or less to issue. For example, 0 years measures all patents with a prosecution time of 0 years, 1 year measures all patents with a prosecution time of less than 1 year; 2 years measures all patents with a prosecution time of less than 2 years (this includes all patents with a prosecution time of 0 years up to 2 years); 3 years measures all patents with a prosecution time of less than 3 years (this includes all patents with a prosecution time of 0 up to 3 years), etc.

${ }^{206}$ Inverse cumulative measures all patents that were still pending at the PTO at the given year. For example, 0 years measures the number of patents still pending at the PTO (100\%), 1 year measures the patents still pending after one year (95.09\%), 2 years measures the patents still pending after two years (51.73\%).
} 


$\begin{array}{rrrrrr}26 & 65 & 0.00 & 2224076 & 99.99 & 0.01 \\ 27 & 43 & 0.00 & 2224119 & 99.99 & 0.01 \\ 28 & 43 & 0.00 & 2224162 & 99.99 & 0.01 \\ 29 & 32 & 0.00 & 2224194 & 99.99 & 0.01 \\ 30 & 38 & 0.00 & 2224232 & 99.99 & 0.01 \\ 31 & 36 & 0.00 & 2224268 & 99.99 & 0.01 \\ 32 & 19 & 0.00 & 2224287 & 100.00 & 0.00 \\ 33 & 21 & 0.00 & 2224308 & 100.00 & 0.00 \\ 34 & 13 & 0.00 & 2224321 & 100.00 & 0.00 \\ 35 & 19 & 0.00 & 2224340 & 100.00 & 0.00 \\ 36 & 12 & 0.00 & 2224352 & 100.00 & 0.00 \\ 37 & 12 & 0.00 & 2224364 & 100.00 & 0.00 \\ 38 & 7 & 0.00 & 2224371 & 100.00 & 0.00 \\ 39 & 2 & 0.00 & 2224373 & 100.00 & 0.00 \\ 40 & 6 & 0.00 & 2224379 & 100.00 & 0.00 \\ 41 & 3 & 0.00 & 2224382 & 100.00 & 0.00 \\ 42 & 2 & 0.00 & 2224384 & 100.00 & 0.00 \\ 43 & 1 & 0.00 & 2224385 & 100.00 & 0.00 \\ 44 & 1 & 0.00 & 2224386 & 100.00 & 0.00 \\ 45 & 1 & 0.00 & 2224387 & 100.00 & 0.00 \\ 48 & 1 & 0.00 & 2224388 & 100.00 & 0.00 \\ 52 & 1 & 0.00 & 2224389 & 100.00 & 0.00\end{array}$

